University of Nebraska - Lincoln

DigitalCommons@University of Nebraska - Lincoln

\title{
Limited Occurrence of Denitrification in Four Shallow Aquifers in Agricultural Areas of the United States
}

\author{
Christopher T. Green \\ USGS, ctgreen@usgs.gov \\ Larry J. Puckett \\ USGS \\ John Karl Böhlke \\ USGS \\ Barbara A. Bekins \\ USGS \\ Steven P. Phillips \\ USGS
}

See next page for additional authors

Follow this and additional works at: https://digitalcommons.unl.edu/usgsstaffpub

Part of the Earth Sciences Commons

Green, Christopher T.; Puckett, Larry J.; Böhlke, John Karl; Bekins, Barbara A.; Phillips, Steven P.; Kauffman, Leon J.; Denver, Judith M.; and Johnson, Henry M., "Limited Occurrence of Denitrification in Four Shallow Aquifers in Agricultural Areas of the United States" (2008). USGS Staff -- Published Research. 24. https://digitalcommons.unl.edu/usgsstaffpub/24

This Article is brought to you for free and open access by the US Geological Survey at DigitalCommons@University of Nebraska - Lincoln. It has been accepted for inclusion in USGS Staff -- Published Research by an authorized administrator of DigitalCommons@University of Nebraska - Lincoln. 


\section{Authors}

Christopher T. Green, Larry J. Puckett, John Karl Böhlke, Barbara A. Bekins, Steven P. Phillips, Leon J.

Kauffman, Judith M. Denver, and Henry M. Johnson 


\title{
Limited Occurrence of Denitrification in Four Shallow Aquifers in Agricultural Areas of the United States
}

\author{
Christopher T. Green, ${ }^{*}$ Larry J. Puckett, John Karl Böhlke, Barbara A. Bekins, Steven P. Phillips, Leon J. Kauffman, Judith M. \\ Denver, and Henry M. Johnson USGS
}

The ability of natural attenuation to mitigate agricultural nitrate contamination in recharging aquifers was investigated in four important agricultural settings in the United States. The study used laboratory analyses, field measurements, and flow and transport modeling for monitoring well transects $(0.5$ to $2.5 \mathrm{~km}$ in length) in the San Joaquin watershed, California, the Elkhorn watershed, Nebraska, the Yakima watershed, Washington, and the Chester watershed, Maryland. Ground water analyses included major ion chemistry, dissolved gases, nitrogen and oxygen stable isotopes, and estimates of recharge date. Sediment analyses included potential electron donors and stable nitrogen and carbon isotopes. Within each site and among aquifer-based medians, dissolved oxygen decreases with ground water age, and excess $\mathrm{N}_{2}$ from denitrification increases with age. Stable isotopes and excess $\mathrm{N}_{2}$ imply minimal denitrifying activity at the Maryland and Washington sites, partial denitrification at the California site, and total denitrification across portions of the Nebraska site. At all sites, recharging electron donor concentrations are not sufficient to account for the losses of dissolved oxygen and nitrate, implying that relict, solid phase electron donors drive redox reactions. Zero-order rates of denitrification range from 0 to $0.14 \mu \mathrm{mol} \mathrm{N} \mathrm{L}^{-1} \mathrm{~d}^{-1}$, comparable to observations of other studies using the same methods. Many values reported in the literature are, however, orders of magnitude higher, which is attributed to a combination of method limitations and bias for selection of sites with rapid denitrification. In the shallow aquifers below these agricultural fields, denitrification is limited in extent and will require residence times of decades or longer to mitigate modern nitrate contamination.

Published in J. Environ. Qual. 37:994-1009 (2008) doi:10.2134/jeq2006.0419

Received 29 Sept. 2006.

*Corresponding author (ctgreen@usgs.gov).
Titrate flux in ground water is an issue of global importance. 1 Nitrate inputs resulting from human activity threaten water quality, especially in agricultural areas where chemical and organic fertilizer applications have increased markedly over the last century (Hallberg and Keeney, 1993; Puckett, 1995; Mueller and Helsel, 1996; Böhlke, 2002). Historical records indicate that the use of nitrogen as commercial fertilizer in the United States has increased more than 20-fold since 1945 (Alexander and Smith, 1990; Ruddy et al., 2006). Nitrate is highly soluble and generally non-sorbing, and it is the most abundant $\mathrm{N}$ contaminant in ground water in the United States (Nolan and Stoner, 2000). This is cause for concern because elevated concentrations of $\mathrm{NO}_{3}{ }^{-}$have been associated with human health risks (World Health Organization, 2004), and when $\mathrm{NO}_{3}^{-}$-laden ground water discharges to surface waters, it contributes to eutrophication (Howarth and Marino, 2006).

Despite the growing interest in contamination and natural remediation of $\mathrm{NO}_{3}{ }^{-}$in ground water, important questions remain about the overall regional and global importance of ground water denitrification (microbial reduction of $\mathrm{NO}_{3}{ }^{-}$to $\mathrm{N}_{2}$ ) (Seitzinger et al., 2006) and the sources of electron donors contributing to this microbial reaction. These questions persist in part because of the difficulties of comparing results from single-site studies that use a wide variety of methods (Groffman et al., 2006). Studies are needed that apply robust methods for measuring denitrification among multiple sites. As a part of the National Water-Quality Assessment Program's investigation of agricultural contamination, this study uses analysis of in situ gradients of stable isotopes, gases, and major ions to evaluate the controlling processes and the rate of denitrification at four agriculturally important sites across the United States.

Although various research studies have documented removal of $\mathrm{NO}_{3}{ }^{-}$via denitrification in individual aquifers (e.g., Trudell et al., 1986; Postma et al., 1991; Smith et al., 1991; Hiscock et al., 1991; Korom, 1992; Böhlke and Denver, 1995; Puckett and Cowdery, 2002; Böhlke et al., 2002; Tesoriero et al., 2005; Korom et al., 2005), the quantitative effects of ground water denitrification within larger regions remain highly uncertain. A recent review of denitrification at

C.T. Green and B.A. Bekins, USGS, 345 Middlefield Rd., Menlo Park, CA 94025; L.J. Puckett and J.K. Böhlke, USGS, 12201 Sunrise Valley Dr., Reston, VA 20192; S.P. Phillips, USGS, 6000 J St., Placer Hall, Sacramento, CA 95819; L.J. Kauffman, USGS, 810 Bear Tavern Rd., West Trenton, NJ 08628; J.M. Denver, USGS, 1289 McD Dr., Dover, Delaware 19901; H.M. Johnson, USGS, 10615 SE Cherry Blossom Dr., Portland, OR 97216.

Abbreviations: AVS, acid volatile sulfide; CA, California; CFC, chlorofluorocarbon; CFIRMS, continuous-flow isotope-ratio mass spectrometry; DOC, dissolved organic carbon; IN, Indiana; MD, Maryland; NE, Nebraska; WA, Washington. 
the global scale (Seitzinger et al., 2006) identified ground water as a potentially important sink for natural and anthropogenic $\mathrm{N}$ in the hydrologic cycle, but the role of ground water denitrification was highly uncertain because of the scarcity of transferable data. Similarly, forward and inverse models of watershed nitrogen fluxes have relatively large uncertainties associated with transport and reaction in ground water (e.g., Bicknell et al., 1997; Schwarz et al., 2006). Many reported rates are for sites that were specifically selected for known or suspected denitrifying activity (e.g., Trudell et al., 1986; Korom et al., 2005). As a result, the potential exists for bias in published rate estimates because of interest in the presence, rather than the absence, of natural attenuation reactions (Commission on Geosciences, Environment, and Resources, 2000). To improve assessment of the range of denitrification rates in regional ground water, previous analyses need to be combined with newer studies that investigate denitrification in multiple aquifers chosen for a range of important agricultural settings and without regard for the expected rates.

Questions remain as to the sources of electron donors that react with $\mathrm{NO}_{3}{ }^{-}$in shallow aquifers. In denitrification, $\mathrm{NO}_{3}{ }^{-}$ serves as the terminal electron acceptor for bacteria that derive energy from the oxidation of a reduced substance. For electron donors, microbes commonly rely on organic $\mathrm{C}$ or, in the case of autolithotophs, reduced forms of S or Fe (Korom, 1992). Several studies have identified solid phases in aquifers as sources of electron donors for denitrification (Kölle et al., 1985; van Beek and van Puffelen, 1987; Frind et al., 1990; Postma et al., 1991; Böhlke and Denver, 1995; Robertson et al., 1996; Tesoriero et al., 2000; Böhlke et al., 2002; Böhlke et al., 2007). Dissolved organic carbon (DOC) in recharging ground water can also serve as an electron donor. Few studies have provided direct measurement of relict and recharging electron donors, and the relative contribution of recharging electron donors remains an area of active research (van Beek and van Puffelen, 1987; Starr and Gillham, 1993; Puckett and Cowdery, 2002; Siemens et al., 2003). Additional work is needed to understand the relative contribution of relict and recharging electron donors in agricultural settings.

Among methods to estimate denitrification rates at the scale of aquifers and larger, analysis of in situ concentration gradients of environmental (as opposed to injected) tracers has several advantages. Although biological samples and assays can provide important information about potential rates and microbial communities involved in denitrification, the rates derived from such methods are typically not representative of in situ rates at the scale of aquifers (Groffman et al., 2006). Sampling of ground water from observation wells minimally perturbs the system as compared to installation of microcosms, injection of solutes, or analysis in the laboratory of sediment cores or slurries. Because $\mathrm{NO}_{3}{ }^{-}$concentration gradients can result from the spatial or temporal variability of source concentrations it is important to include analyses of $\mathrm{N}_{2}$ in assessments of denitrification progress and rates (Vogel et al., 1981; Böhlke and Denver, 1995; Böhlke, 2002; Böhlke et al., 2002; Puckett and Cowdery, 2002). In addition, in situ gradients of stable isotopes can provide substantiating evidence as to the extent of denitrification as well as historical changes in sources. Combining these data with measurements of environmental age tracer concentrations allows estimation of denitrification rates at the scale of aquifers. Few studies have conducted a complete, simultaneous analysis of the various $\mathrm{N}$ species, particularly $\mathrm{N}_{2}$, coupled with an analysis of the redox processes, stable isotopes, and the ground water flow system involved, leaving many questions unanswered with respect to the true fate of $\mathrm{NO}_{3}^{-}$.

This study uses combined methods including analyses of majorelement chemistry, dissolved gases, and stable isotopes, as well as age dating and numerical flow modeling to evaluate the extent of mitigation of nitrate contamination by denitrification in contrasting aquifers that are representative of important agricultural settings across the United States. At four shallow, sandy aquifers overlain by a wide range of unsaturated zone, climatic, and agricultural conditions, a single study approach is used to identify the histories of $\mathrm{NO}_{3}{ }^{-}$transport and denitrification in areas of recharging ground water. This article identifies the spatial variations in $\mathrm{NO}_{3}{ }^{-}$ distribution and denitrification and examines the role of physical and chemical processes in controlling these variations. Denitrification rates are estimated and are compared to previous studies to evaluate the broader importance of denitrification in the types of shallow agricultural aquifers represented by these four study sites.

\section{Site Descriptions}

Four study sites were chosen in agricultural watersheds in the San Joaquin River watershed, California (CA); Elkhorn River watershed, Nebraska (NE); the Yakima River watershed, Washington (WA); and the Chester River watershed on the Delmarva Peninsula, Maryland (MD) (Fig. 1). All four study sites are underlain by sandy aquifers (63 to $89 \%$ sand and gravel) with low organic matter content ( 0.8 to $2.3 \%$ ) and several meters of overlying unsaturated zone. More detailed descriptions of the surficial sedimentary geology are provided in Table 1 . The water table was generally within $10 \mathrm{~m}$ of the land surface at the MD, WA, and CA sites, but reached a maximum of $22 \mathrm{~m}$ at NE. Saturated thicknesses of the aquifers range from $16 \mathrm{~m}$ at $\mathrm{MD}$ to $31 \mathrm{~m}$ at $\mathrm{CA}$ and $\mathrm{NE}$, to 100 $\mathrm{m}$ at WA. Climates, irrigation practices, and crop types contrast among the sites. Climates ranged from arid/semiarid at the western sites (WA and CA) to humid continental at the mid-continent (NE) and humid subtropical at the eastern coast (MD) sites. The arid sites receive the majority of water during the growing season from irrigation from surface water diversions, which supports a wide variety of crops such as fruit and nut orchards, corn [Zea mays L.], pasture, vineyards, and vegetables. The main crop types at the humid sites are corn and soybeans [Glycine max (L.) Merr.] planted in rotation. Additional details of the characteristics of the watersheds containing each of these sites can be found in Capel (2008).

Although detailed historical data on land use were not available, some information was obtained from land owners at MD, WA, and NE, and from aerial photos of the CA site. According to the current land owners at the fields in the immediate vicinity of the MD transect, these fields have been in corn-soybean rotations for at least $20 \mathrm{yr}$. In the mid-1990s the fields switched from conventional tillage to no-till agriculture. At the same time, the use of chicken manure was replaced by chemical fertilizer. At WA, the largest changes in land use include a decline in sugar beet production following the 1950 s, a decline in asparagus production 
A

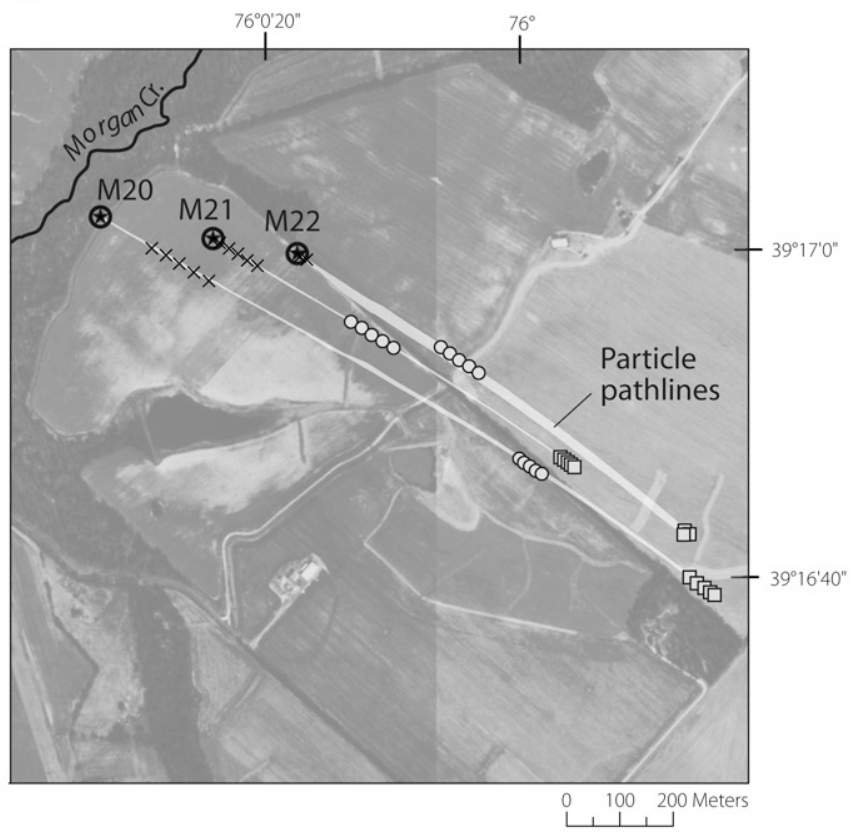

C

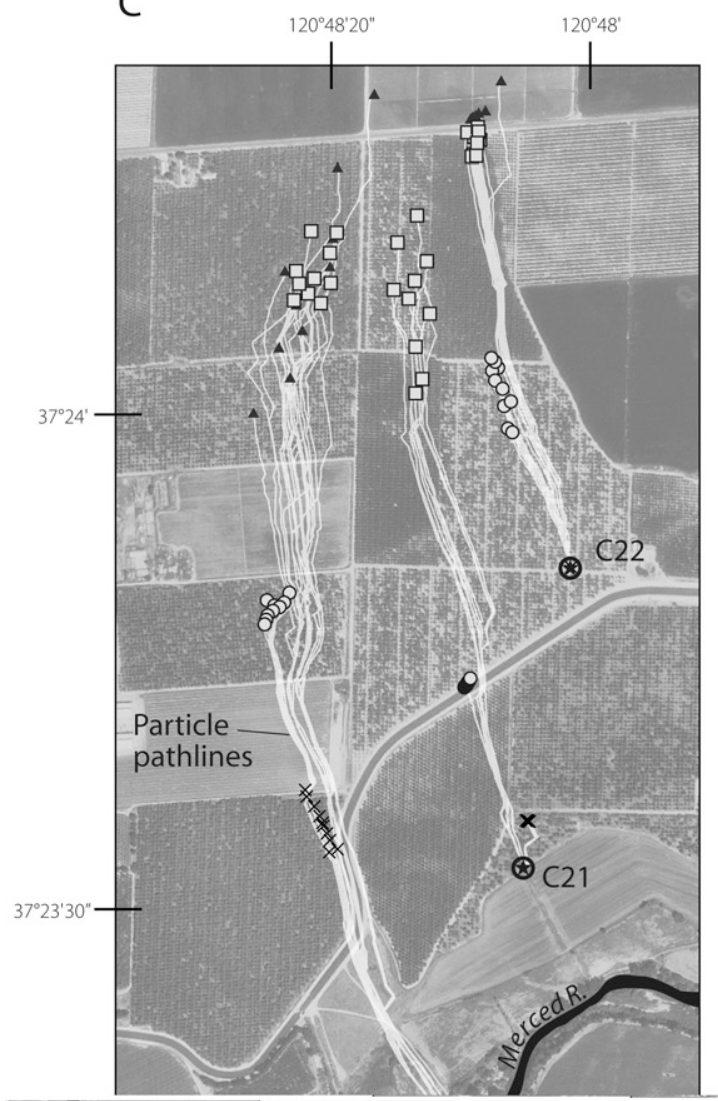

B

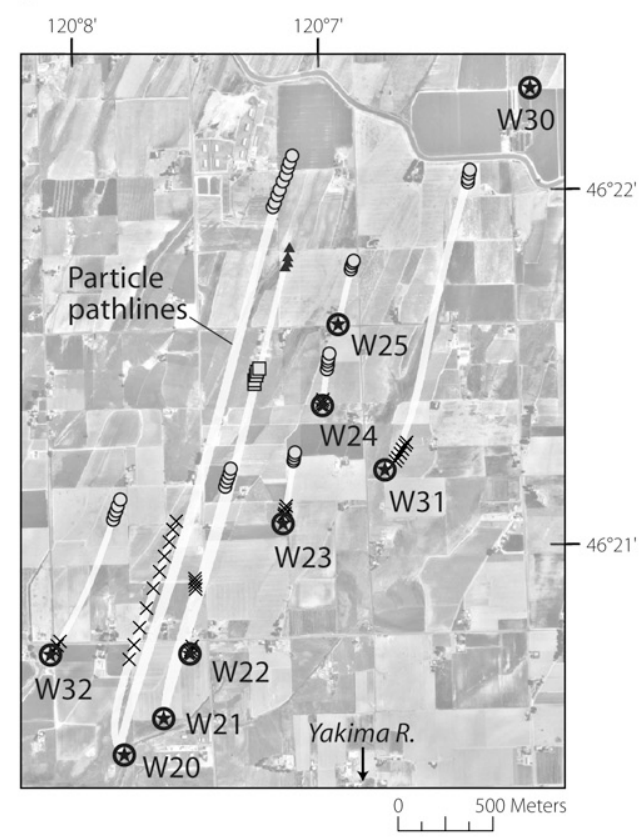

D

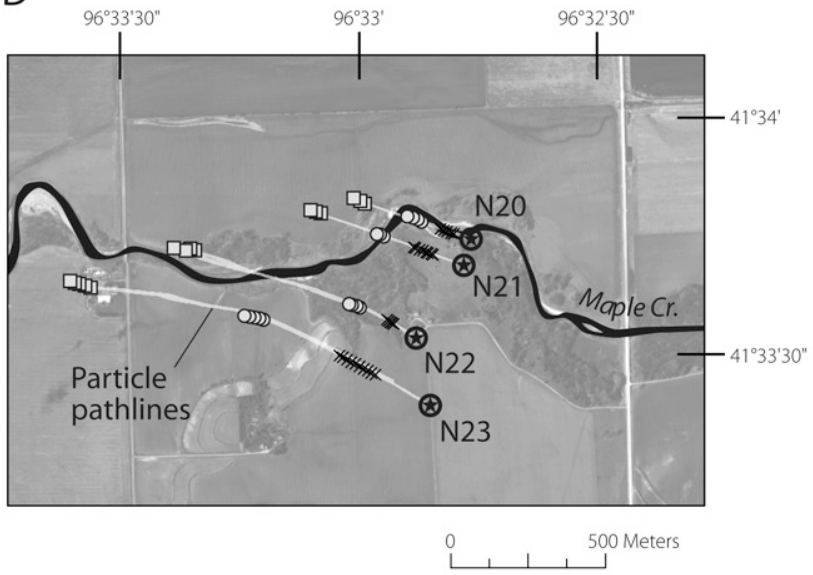

(주 C20 Well nest and I.D.

Contributing point to:

$\times$ Highest well in nest

0 2nd highest well in nest

$\square$ 3rd highest well in nest

A 4th highest well in nest

Fig. 1. Plan view maps showing well nest locations and names, simulated backward particle tracking paths, and simulated source locations for each particle for (A) Maryland, (B) Washington, (C) California, and (D) Nebraska.

following the 1970s, and increased dairy production along with associated corn and feed grass crops over the last several decades. At $\mathrm{NE}$, the crop types in the vicinity of the well transect are believed to have been corn and soybeans for the last several decades. At CA, aerial photographs and land-use maps show that the source area was at the eastern edge of local farm lands in the mid-1940s. Row 
Table 1. Characteristics of well transect areas in Maryland (MD), Washington (WA), California (CA), and Nebraska, (NE).

\begin{tabular}{|c|c|c|c|c|}
\hline \multirow[b]{2}{*}{ Characteristic } & \multicolumn{4}{|c|}{ Study site } \\
\hline & MD & WA & CA & NE \\
\hline Sand \& gravel $\left(\mathrm{g} \mathrm{g}^{-1}\right) \dagger$ & 0.78 & 0.63 & 0.77 & 0.89 \\
\hline Organic matter $\left(\mathrm{g} \mathrm{g}^{-1}\right) \ddagger$ & 0.023 & 0.023 & 0.012 & 0.008 \\
\hline $\begin{array}{l}\text { Surficial aquifer saturated } \\
\text { thickness }(\mathrm{m})\end{array}$ & 16 & 100 & 31 & 31 \\
\hline Depth to water $(\mathrm{m}) \S$ & $0-11 \mathrm{~m}$ & $0-14 \mathrm{~m}$ & $5-10 m$ & $3-22 m$ \\
\hline $\begin{array}{l}\text { Sedimentary geology } \\
\text { (from shallow to deep) }\end{array}$ & $\begin{array}{l}\text { (A) Thin layer of quartz } \\
\text { sands and gravels } \\
\text { (B) Coarsening- } \\
\text { upward muddy } \\
\text { glauconitic sand }\end{array}$ & $\begin{array}{l}\text { (A) 3-10 m of flood deposited sandy silt } \\
\text { dissected by sub-vertical clastic dikes } \\
\text { (B) Sequences of loess, debris flows, } \\
\text { aluvium, colluvium, and fluvial sands } \\
\text { and cobbles }\end{array}$ & $\begin{array}{l}\text { (A) Thin layer of } \\
\text { unsaturated, eolian sands } \\
\text { (B) Alluvial sands, silts, and } \\
\text { clays } \\
\text { (C) Lacustrine clay }\end{array}$ & $\begin{array}{l}\text { (A) Unsaturated loess } \\
\text { (B) Terraced sand and } \\
\text { gravel deposits }\end{array}$ \\
\hline Climate & humid subtropical & arid & arid to semiarid & humid continental \\
\hline Crops in source area & $\begin{array}{l}\text { corn, soybeans, small } \\
\text { grains, pasture, hay }\end{array}$ & $\begin{array}{l}\text { corn, pasture, grapes, asparagus, alfalfa, } \\
\text { hops, mint, dairies, orchards, grasses }\end{array}$ & orchards, corn, vegetables & $\begin{array}{l}\text { corn, soybeans, alfalfa, } \\
\text { pasture }\end{array}$ \\
\hline Precipitation $\left(\mathrm{cm} \mathrm{yr}^{-1}\right)$ & 112 & 19 & 31 & 72 \\
\hline Irrigation $\left(\mathrm{cm} \mathrm{yr}^{-1}\right)$ & 0 & 74 & 120 & 20 \\
\hline Irrigation delivery method & none & $\begin{array}{l}\text { sprinkler, furrow, micro-sprinkler, drip, } \\
\text { and other methods }\end{array}$ & $\begin{array}{l}\text { basin, sprinkler, furrow, } \\
\text { micro-sprinkler, drip. }\end{array}$ & center-pivot sprinklers \\
\hline Irrigation source & none & surface water diversions & surface water diversions & ground water wells \\
\hline Recharge $\left(\mathrm{cm} \mathrm{yr}^{-1}\right) \mathfrak{q}$ & 32 & 12 & 42 & $5-16$ \\
\hline \multicolumn{5}{|c|}{$\begin{array}{l}\text { † Average of all samples from each site analyzed by sieving of the gravel fraction and laser dispersive particle size analysis of the finer fractions. Grave } \\
\text { comprised } 0.07 \mathrm{~g} \mathrm{~g}^{-1} \text { of sediments at WA and minor amounts }\left(<0.01 \mathrm{~g} \mathrm{~g}^{-1}\right) \text { at other sites. }\end{array}$} \\
\hline \multicolumn{5}{|c|}{ ‡ Calculated by loss on ignition of aquifer materials. } \\
\hline \multicolumn{5}{|c|}{$\S$ Based on minimum and maximum measured water levels in wells at times of sampling. } \\
\hline \multicolumn{5}{|c|}{ I Recharge for MD, WA, and CA is from Fisher and Healy (2008). NE recharge is from Green et al. (2008). } \\
\hline
\end{tabular}

crops and livestock dominated agriculture in the source area until the early 1960s, when orchards began to replace pastures and fields. By the mid 1990s the source area was almost entirely orchards, and has remained the same until the present. Information from land owners and aerial photographs indicates that the percentages of agricultural land in the vicinities of the well transects have remained constant over the last 50 to $100 \mathrm{yr}$.

\section{Materials and Methods}

This study involved installation of ground water wells and collection of soil and water samples for a variety of analyses. Most wells were sampled four times during 2004. All rounds of samples were analyzed for major-ion chemistry and nutrients. One round of samples from each site was analyzed for dissolved gases, $\mathrm{N}$ and $\mathrm{O}$ isotopes, and age-dating environmental tracers. Sediment analyses included potential electron donors and stable isotopes of $\mathrm{N}$ and $\mathrm{C}$. Most of the methods of instrumentation, sampling, and chemical analysis used for this work are described in the supplemental section in this issue (Capel, 2008). Correlations among solute concentrations were estimated using Pearson product-moment correlation coefficients and $P$ values calculated with SigmaStat (Systat Software Inc., 2006). Special analyses and other techniques are described below.

\section{Well Installation}

At each study location, multiple well nests were installed along transects that extended from the edge of a stream up the topographic gradient to a distance of approximately $0.5 \mathrm{~km}$ at $\mathrm{MD}$ and NE, $1 \mathrm{~km}$ at CA, and $2.5 \mathrm{~km}$ at WA. Each transect included one well nest in or near the riparian zone adjacent to the ground water/surface water interaction study area (Puckett et al., 2008). Upgradient well nests were located in ground water recharge areas beneath agricultural fields and were collocated with unsaturated zone study locations (Green et al., 2008). The length and location of each transect was constrained in part by practical considerations such as land owner permissions. At each well nest, multiple well screens were installed to extend to approximately $10 \mathrm{~m}$ below the water table at $\mathrm{MD}$ and $\mathrm{NE}$ and approximately $25 \mathrm{~m}$ below the water table at $\mathrm{CA}$ and WA. Each drilling site was assigned a three digit code (Fig. 1). Individual well screens were assigned a four digit code by appending the well location code with a letter starting with "p" for the shallowest screen and subsequent letters for deeper screens. Wells were constructed of 5-cm-diameter polyvinyl chloride pipe with slotted screens and were typically installed using hollow-stem augers. The annulus around the screen was filled with silica sand, and the remaining annulus was grouted with bentonite, with a cement cap at land surface. Well installation followed standard procedures as described in Lapham et al. (1997).

\section{Dissolved Gases and Denitrification Progress}

Dissolved $\mathrm{N}_{2}$ and Ar concentrations were used to estimate the quantities in ground water of dissolved gases originating from atmospheric and biological sources (Heaton and Vogel, 1981; Vogel et al., 1981; Böhlke and Denver, 1995; McMahon and Böhlke, 1996; Puckett et al., 2002; Böhlke et al., 2002). Samples for analysis of dissolved $\mathrm{N}_{2}$ and Ar were collected in filled serum bottles with no headspace and analyzed by gas chromatography after creation of low-pressure headspace in the 
laboratory (http://water.usgs.gov/lab/dissolved-gas/; verified 24 July 2007). Contamination and degassing were minimized by sampling using positive displacement pumps. Results of the analyses were corrected for solubility in sample water at laboratory temperatures and have typical uncertainties of \pm 1 to $2 \%$.

In ground water, dissolved gases may originate from equilibrium exchange with the atmosphere at the water table, dissolution of entrapped air bubbles, and production by reactions such as denitrification. Typically, dissolved gases include some fraction from bubbles of air that become trapped under recharging water and entrained in the saturated zone. As long as the hydrostatic pressure remains greater than the total pressure of gases in solution, degassing is unlikely (Blicher-Mathiesen et al., 1998). Similarly, denitrification produces $\mathrm{N}_{2}$ that remains in solution in recharging ground water. Recent literature has used the terms "excess air" to refer to atmospheric gases originating from entrained bubbles, and "excess $\mathrm{N}_{2}$ " to refer to $\mathrm{N}_{2}$ originating from denitrification.

Excess air and excess $\mathrm{N}_{2}$ concentrations in ground water were estimated using the concentrations of $\mathrm{N}_{2}$ and Ar, their solubility in water (Weiss, 1970), the atmospheric pressure, and the recharge temperature. This calculation required several assumptions, including (i) the only source of Ar was the atmosphere, (ii) the only sources of $\mathrm{N}_{2}$ were the atmosphere and denitrification, and (iii) excess air was not fractionated. In addition, it was assumed that all samples at each study site were recharged at the same temperature, but with varying amounts of excess air. The latter assumption is considered to be the largest source of uncertainty because of possible variations in recharge temperatures, but in the absence of other noble gas measurements, this procedure minimizes errors associated with minor air contamination or partial degassing during sampling (Böhlke et al., 2002). The recharge temperature was based on the annual average ground water temperature in monitoring wells near the water table $\left(13.0^{\circ} \mathrm{C}\right.$ at $\mathrm{MD}, 13.3^{\circ} \mathrm{C}$ at WA, $19.2^{\circ} \mathrm{C}$ at $\mathrm{CA}$, and $10.8^{\circ} \mathrm{C}$ at $\left.\mathrm{NE}\right)$. The excess air concentration in each sample was calculated with

$\left[\right.$ air $\left._{\text {bub }}\right]=\frac{\left[\mathrm{Ar}_{\text {meas }}\right]-\left[\mathrm{Ar}_{\text {equil }}\right](\mathrm{T}, \text { elev })}{0.417}$

where [air $\left.{ }_{b u b}\right]$ is the concentration of excess air from entrained bubbles $\left(\mathrm{cm}^{3} \mathrm{~L}^{-1}\right),\left[\mathrm{Ar}_{\text {meas }}\right]$ is the measured concentration of $\mathrm{Ar}$ in the sample $(\mu \mathrm{mol} \mathrm{L}-1),\left[\mathrm{Ar}_{\text {equil }}\right](T$,elev $)$ is the concentration of $\mathrm{Ar}$

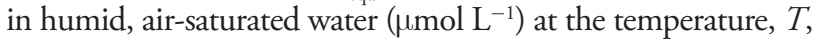
and elevation, elev, of the water table, and 0.417 is the conversion factor for the quantity of Ar per volume of air $\left(\mu \mathrm{mol} \mathrm{cm}^{-3}\right)$ at standard temperature and pressure of $1 \mathrm{~atm}$ and $0^{\circ} \mathrm{C}$. The excess $\mathrm{N}_{2}$ derived from denitrification was then calculated using

$\left[\mathrm{N}_{2, \text { bub }}\right]=\left[\right.$ air $\left._{\text {bub }}\right] \cdot 34.8$

and

$\left[\mathrm{N}_{2, \text { denit }}\right]=\left[\mathrm{N}_{2, \text { meas }}\right]-\left[\mathrm{N}_{2, \text { equil }}\right](\mathrm{T}$, elev $)-\left[\mathrm{N}_{2, \text { bub }}\right]$

where $\left[\mathrm{N}_{2, \text { bub }}\right]$ is the $\mathrm{N}_{2}$ from entrained bubbles $\left(\mu \mathrm{mol} \mathrm{L}{ }^{-1}\right)$, 34.8 is the conversion factor for the quantity of $\mathrm{N}_{2}$ per volume of air $\left(\mu \mathrm{mol} \mathrm{cm}{ }^{-3}\right)$ at standard temperature and pressure, $\left[\mathrm{N}_{2, \text { denit }}\right]$ is the $\mathrm{N}_{2}$ from denitrification $\left(\mu \mathrm{mol} \mathrm{L}^{-1}\right)$, $\left[\mathrm{N}_{2 \text {,meas }}\right]$ is the measured concentration of $\mathrm{N}_{2}$ in the sample $\left(\mu \mathrm{mol} \mathrm{L}^{-1}\right)$, and $\left[\mathrm{N}_{2, \text { equil }}\right](T$,elev $)$ is the concentration of $\mathrm{N}_{2}$ in air-saturated water as a function of $T$ and elev.

The cumulative progress of denitrification that has occurred in a ground water sample is given by the concentration of $\mathrm{N}_{2, \text { denit }}$ and it can also be expressed as the fraction of the original $\mathrm{NO}_{3}{ }^{-}$that has been denitrified $\left(\xi_{\text {denit }}\right)$ :

$\xi_{\text {denit }}=\frac{2 \cdot\left[\mathrm{N}_{2, \text { denit }}\right]}{\left[\mathrm{NO}_{3}^{-}\right]^{0}}$

where $\left[\mathrm{NO}_{3}^{-}\right]^{0}$ is the reconstructed (initial) concentration of $\mathrm{NO}_{3}^{-}$before denitrification:

$$
\left[\mathrm{NO}_{3}^{-}\right]^{0}=\left[\mathrm{NO}_{3}^{-}\right]+2 \cdot\left[\mathrm{N}_{2, \text { denit }}\right]
$$

For example, a value of 0.5 for $\xi_{\text {denit }}$ would indicate that half of the original $\mathrm{NO}_{3}{ }^{-}$had been denitrified somewhere along the ground water flow path after the water ceased to exchange with unsaturated-zone air in the recharge area. Uncertainties in the reaction progress estimate were caused mainly by uncertainties in the assumed recharge conditions affecting the calculation of $\left[\mathrm{N}_{2, \text { denit }}\right]$.

\section{Stable Isotopes}

The concentrations and isotopic compositions of $\mathrm{NO}_{3}{ }^{-}$and $\mathrm{N}_{2}$ in selected samples were used to assess $\mathrm{NO}_{3}{ }^{-}$sources and effects of denitrification (Vogel et al., 1981; Böhlke et al., 2002). The N and $\mathrm{O}$ isotopic composition of $\mathrm{NO}_{3}{ }^{-}$was determined by bacterial reduction to $\mathrm{N}_{2} \mathrm{O}$ and continuous-flow isotope-ratio mass spectrometry (CFIRMS) (Sigman et al., 2001; Casciotti et al., 2002; Coplen et al., 2004). The isotopic composition of dissolved $\mathrm{N}_{2}$ was determined by gas chromatograph separation and CFIRMS on headspace gas leftover after gas chromatograph analysis of dissolved gas concentrations. The isotope data were normalized according to recommendations in Böhlke and Coplen (1995) and Böhlke et al. (2003). The isotopic composition of the $\left[\mathrm{N}_{2, \text { denit }}\right]$ component, $\delta^{15} \mathrm{~N}\left[\mathrm{~N}_{2, \text { denit }}\right]$, was calculated using a mass balance equation:

$$
\begin{aligned}
& \delta^{15} \mathrm{~N}\left[\mathrm{~N}_{2, \text { denit }}\right]= \\
& \frac{\left[\mathrm{N}_{2, \text { meas }}\right] \cdot \delta^{15} \mathrm{~N}\left[\mathrm{~N}_{2, \text { meas }}\right]-\left[\mathrm{N}_{2, \text { equil }}\right] \cdot \delta^{15} \mathrm{~N}\left[\mathrm{~N}_{2, \text { cquil }}\right]-\left[\mathrm{N}_{2, \text { bub }}\right] \cdot \delta^{15} \mathrm{~N}\left[\mathrm{~N}_{2, \text { bub }}\right]}{\left[\mathrm{N}_{2, \text { denit }}\right]}
\end{aligned}
$$

where $\delta^{15} \mathrm{~N}\left[\mathrm{~N}_{2, \text { equil }}\right]=+0.7 \%$ and $\delta^{15} \mathrm{~N}\left[\mathrm{~N}_{2, \text { bub }}\right]=0.0 \%$. The $\delta^{15} \mathrm{~N}$ value of the initial $\left.\mathrm{NO}_{3}^{-},\left(\delta^{15} \mathrm{~N}^{2} \mathrm{NO}_{3}{ }^{-}\right]^{0}\right)$, then was calculated from mass balance:

$\delta^{15} \mathrm{~N}\left[\mathrm{NO}_{3}^{-}\right]^{0}=\frac{\left[\mathrm{NO}_{3}^{-}\right] \cdot \delta^{15} \mathrm{~N}\left[\mathrm{NO}_{3}^{-}\right]+2 \cdot\left[\mathrm{N}_{2, \text { denit }}\right] \cdot \delta^{15} \mathrm{~N}\left[\mathrm{~N}_{2, \text { denit }}\right]}{\left[\mathrm{NO}_{3}^{-}\right]^{0}}$

Additional isotopic analyses were done on sediment samples for $\delta^{15} \mathrm{~N}$ and $\delta^{13} \mathrm{C}$ and water samples for $\delta^{18} \mathrm{O}$ (http://isotopes.usgs. gov; verified 24 July 2007). Sediments were collected from the upper $0.5 \mathrm{~m}$ near selected well nests and from drilled cores below 
the water table. Sediments were dried, ground, homogenized, and analyzed for $\delta^{15} \mathrm{~N}$ and $\delta^{13} \mathrm{C}$ by CFIRMS following decomposition in an elemental analyzer. Data were normalized as described in Qi et al. (2003), with typical reproducibilities of $\pm 0.5 \%$ (2-sigma). For $\delta^{13} \mathrm{C}$ of the organic carbon fraction, samples were acid treated to remove carbonates before decomposition. Water samples were analyzed by $\mathrm{CO}_{2}$ equilibration and dual-inlet mass spectrometry, normalized to Vienna Standard Mean Ocean Water and Standard Light Antarctic Precipitation with typical reproducibilities of \pm 0.2 $\%$ (2-sigma).

\section{Ground Water Dating by Chlorofluorocarbons, Sulfur Hexafluoride, and Tritium}

Samples for analyses of the chlorofluorocarbons $\mathrm{CFCl}_{3}$ (CFC-11), $\mathrm{CF}_{2} \mathrm{Cl}_{2}$ (CFC-12), and $\mathrm{C}_{2} \mathrm{~F}_{3} \mathrm{Cl}_{3}$ (CFC-113) were collected in glass bottles with aluminum-lined caps and analyzed by electron-capture gas chromatography with a detection limit of $0.3 \mathrm{pg} \mathrm{kg}^{-1}$ for CFC-11 and CFC-12, and $1.0 \mathrm{pg} \mathrm{kg}^{-1}$ for CFC-113 (Busenberg and Plummer, 1992; http://water.usgs. gov/lab/cfc/; verified 24 July 2007). Samples for analysis of sulfur hexafluoride $\left(\mathrm{SF}_{6}\right)$ were collected in glass bottles with polyseal plastic-lined caps and analyzed by electron-capture gas chromatography with a detection limit of $0.01 \mathrm{fmol} \mathrm{L}^{-1}$ and a precision of about $20 \%$ near the detection limit and about $3 \%$ at concentrations above $0.1 \mathrm{fmol} \mathrm{L}^{-1}$ (Busenberg and Plummer, 2000).

For this study, two methods were used to estimate recharge dates based on measured concentration of tracers. First, piston flow estimates of "apparent" ages were assigned on the basis of a comparison of CFC or $\mathrm{SF}_{6}$ equilibrium partial pressures, corrected for recharge temperature and excess air with chronologies of atmospheric concentrations (Busenberg and Plummer, 1992, 2000). This has been a common approach in previous studies using ground water ages to calculate denitrification rates. It relies on the assumption that all water in a sample is recharged at the same time and that the concentration of age-dating tracers in the sample is identical to the concentration at the water table at the time of recharge. In a few cases, tritium was used for quality assurance to screen for possible gross errors in $\mathrm{CFC}$ or $\mathrm{SF}_{6}$ age dates. Tritium samples were collected in safety-coated glass bottles sealed with polyseal plastic-lined caps. Tritium was enriched by electrolysis and analyzed by liquid scintillation counting (Thatcher et al., 1976) with an analytical uncertainty of approximately \pm 0.7 tritium unit. Permissible age ranges were assigned by comparing chronologies of tritium in rainwater decayed to the present.

The second method for estimating ages was a "mixed-age" analysis. Ground water dispersion and sampling across a range of depths can result in samples that contain a mixture of waters of different ages. In such cases, the average age can differ substantially from the piston flow age estimate from a single tracer (Zuber, 1986; Cook and Böhlke, 2000; Weissmann et al., 2002). For CFC dating, the discrepancy is small for waters younger than 20 to 30 $\mathrm{yr}$, such as at the MD site. The discrepancy increases with age, however, and is potentially significant for the older waters at the $\mathrm{CA}, \mathrm{NE}$, and WA sites. To account for possible effects of mixing of different waters on apparent ground water ages, age distributions were assigned to individual samples. For NE and WA, multiple age-dating tracers were available for most samples. For these samples, several dozen unimodal and bimodal discrete-age probability density functions were manually constructed by assigning ad hoc proportions across the range of ages to represent interpretations of possible mixing scenarios. To calculate modeled tracer concentrations, the atmospheric concentration record was used to assign concentrations to each age category. Concentration was multiplied by the proportion of water in that category, and the overall concentration was determined by summing these products for all age categories. The age distribution that reproduced the measured tracer concentrations was chosen as the best fit scenario.

At CA, multiple age tracers were generally not available. For each CA sample, a discrete-age probability density function was estimated using the backward random-walk particle-tracking approach outlined in Weissmann et al. (2002) with a dispersivity of $4 \mathrm{~cm}$. Modeled tracer concentrations were calculated in the same manner as for NE and WA. For each well screen, models were fitted to data by shifting all age categories in the probability density function up or down by a uniform offset until the mean tracer concentration matched the observed value. For the CA, NE, and WA data, the arithmetic averages of the best-fit age probability density functions were used as the mixed-age estimates.

\section{Solid Phase Electron Donors and Mineralogy}

To estimate the concentration of electron donors in sediments, cores were analyzed for mineralogy, Fe(II), Fe(III), and sulfides. Mineralogy was determined by X-ray diffraction. Iron species were characterized using hydrochloric acid and hydroxylamine extractions. Sulfides in the form of acid-volatile sulfide (AVS) and pyrite-S were characterized by a variety of methods (see Puckett et al., 2008).

\section{Numerical Modeling}

The MODFLOW code (Harbaugh et al., 2000) was used to develop three-dimensional numerical models of ground water flow in the vicinity of the well transects at all four sites. Flow models were manually calibrated using MODFLOW's parameter estimation routines and with manual adjustments to match hydraulic heads measured in observation wells, surface water elevations, and observations of hydraulic gradients in the stream beds. All models were steady-state and approximated the average base flow conditions. To constrain the flow and boundary conditions of local-scale site models, the model domains were nested within existing regional-scale flow models. Additional details about model construction and calibration are available in Capel (2008).

The flow vectors from the local-scale models were used to run backward advective particle tracking in MODPATH (Pollock, 1994), which allows estimation of the recharge source areas contributing to each well screen (e.g., Modica et al., 1998; Rayne et al., 2001; Paradis et al., 2007). For all study locations, digitized maps of crop types and advective particle tracking results were used to characterize the spatial scale and current land use in the source area of each well screen. Source areas for well transects were estimated by drawing a polygon around the particle trajectories associated with all wells within each transect. 


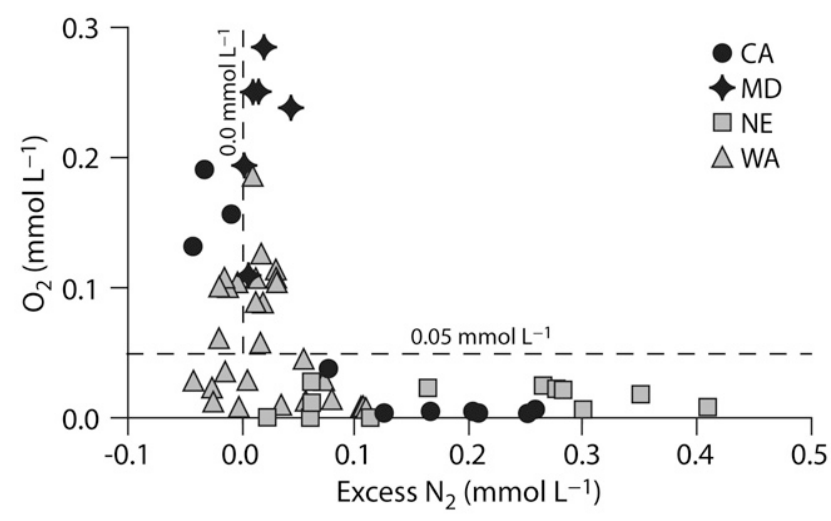

Fig. 2. Excess $\mathrm{N}_{2}$ estimates compared to dissolved $\mathrm{O}_{2}$ concentrations. Two samples from MD (M20q and M20r) were excluded due to apparent mixing of aerobic and denitrified water.

The length of the source area was measured along a line intersecting the approximate center of the source area for each well in the array. In addition, average path lengths were computed for each well based on all particles contributing to that well.
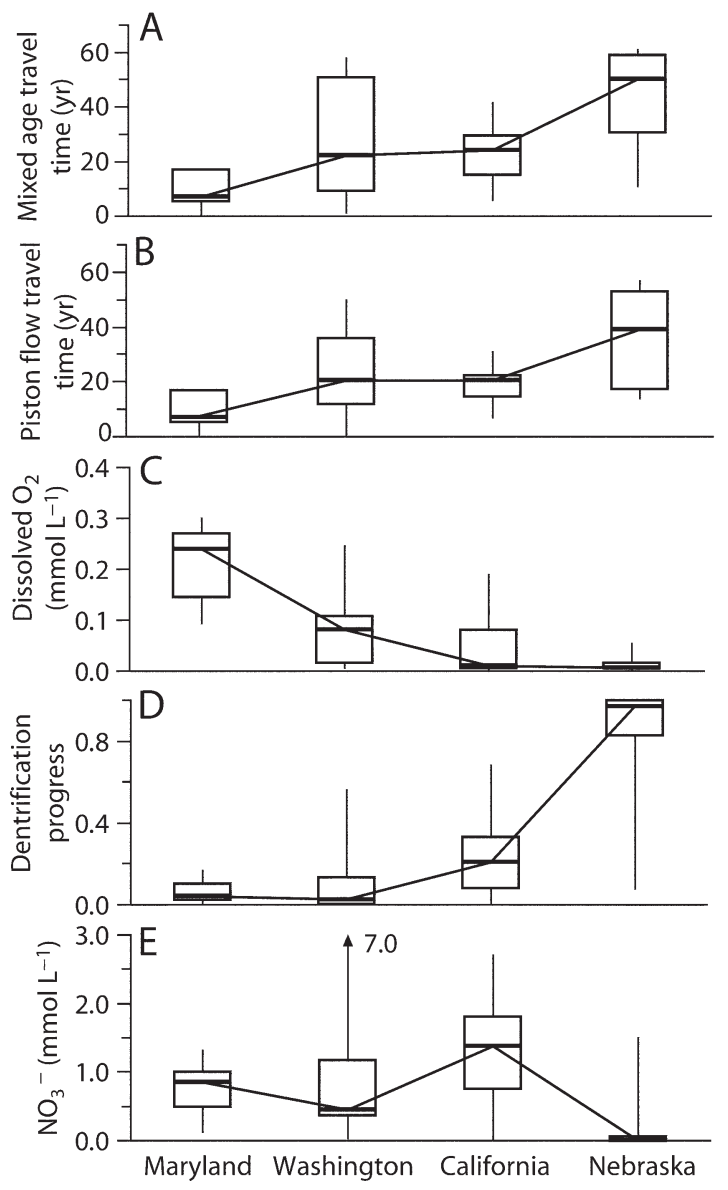

Fig. 3. Distributions in all ground water samples from each site of (A) average age with mixing (piston flow ages shown for Maryland, where mixed ages were not calculated), (B) piston flow age, (C) dissolved $\mathrm{O}_{2^{\prime}}(\mathrm{D})$ denitrification progress (proportion of initial nitrate in ground water subsequently converted to $\mathrm{N}_{2}, \xi_{\text {denit }}$ in Eq. [4]), and (E) $\mathrm{NO}_{3}^{-}$. Error bars show the minimum and maximum values, boxes show the interquartile range, and horizontal lines inside the boxes show the median.

\section{Results and Discussion}

\section{Uncertainty in Excess $\mathrm{N}_{2}$ Estimates}

To assess the uncertainty in excess $\mathrm{N}_{2}$ estimates resulting from the assumption of uniform recharge temperature at each site, an analysis was conducted of the variability of excess $\mathrm{N}_{2}$ estimates as a function of $\mathrm{O}_{2}$ concentrations (Fig. 2). This plot shows an abrupt transition, with excess $\mathrm{N}_{2}$ varying widely for samples with $<0.05 \mathrm{mmol} \mathrm{L}^{-1} \mathrm{O}_{2}$, and remaining close to $0 \mathrm{mmol} \mathrm{L}^{-1}$ for samples with $>0.05 \mathrm{mmol} \mathrm{L}^{-1} \mathrm{O}_{2}$. This latter group is consistent with undenitrified waters containing high $\mathrm{O}_{2}$ and low excess $\mathrm{N}_{2}$. The apparent $\mathrm{O}_{2}$ cutoff for denitrification in these aquifers is similar to a value of $0.06 \mathrm{mmol} \mathrm{L}^{-1} \mathrm{O}_{2}$ reported for a site in Minnesota (Böhlke et al., 2002). Lower cutoff values are sometimes used to delineate environments suitable for denitrification (e.g., $0.016 \mathrm{mmol} \mathrm{L}^{-1} \mathrm{O}_{2}$; Chapelle et al., 1995). Samples with $<0.05 \mathrm{mmol} \mathrm{L}^{-1} \mathrm{O}_{2}$ in this study may contain mixtures of anaerobic and aerobic ground waters. In following discussions, samples with $\mathrm{O}_{2}>0.05 \mathrm{mmol} \mathrm{L}-1$ will be referred to as "strictly aerobic."

The calculated excess $\mathrm{N}_{2}$ values in strictly aerobic samples are normally distributed (Kolmogorov-Smirnov $P>0.2$; Systat Software Inc., 2006) with an average of $0.005 \pm$ $0.010 \mathrm{mmol} \mathrm{L}^{-1}$ (95\% confidence interval), a standard deviation of $0.022 \mathrm{mmol} \mathrm{L}^{-1}$, and a $95 \%$ prediction interval of $\pm 0.047 \mathrm{mmol} \mathrm{L}^{-1}$. Because the mean does not differ significantly from $0 \mathrm{mmol} \mathrm{L}^{-1}$ excess $\mathrm{N}_{2}$, which is the expected value for undenitrified samples, there is no indication of bias in the excess $\mathrm{N}_{2}$ estimates.

\section{Inter-site Comparison of $\mathrm{NO}_{3}{ }^{-}$Concentrations and Denitrification at the Aquifer Scale}

To provide a general overview and comparison of $\mathrm{NO}_{3}{ }^{-}$and redox chemistry among sites, the medians and interquartiles of travel times, $\mathrm{O}_{2}$, denitrification progress, and $\mathrm{NO}_{3}{ }^{-}$were calculated for each site (Fig. 3). The median values for each site are based on the full set of data from all monitoring wells at that site. The results reveal broad-scale geochemical trends indicating that, despite differences in hydrology and land use, these four aquifers can be seen to represent different stages along a gradual and consistent progression of redox conditions. Study locations with old median ground water ages tend to have low median dissolved $\mathrm{O}_{2}$ concentrations. From MD to WA to CA to NE, a trend of increasing age (in both piston flow and mixing based estimates) corresponds to a trend of decreasing $\mathrm{O}_{2}$ concentrations (Fig. 3). Along with the trend in $\mathrm{O}_{2}$ concentration, the prevalent electron acceptors (as determined using the hierarchical scheme of Paschke et al. (2007) shift from $\mathrm{O}_{2}$ at $\mathrm{MD}$ to $\mathrm{SO}_{4}^{2-}, \mathrm{Mn}(\mathrm{IV}), \mathrm{Fe}(\mathrm{III}), \mathrm{NO}_{3}^{-}$, and $\mathrm{O}_{2}$ at NE. Among all four study locations, the correlations between aquifer-scale median $\mathrm{O}_{2}$, redox status, and age are similar to patterns commonly observed along individual flow paths in aquifers receiving oxic recharge (Champ et al., 1979; Chapelle et al., 1995). The occurrence of such patterns at the aquifer scale implies that the reactive characteristics of these aquifers may be similar, whereas deviations from the correlation between age and redox status would imply more variability in the reaction rates among the sites. To the extent 
that reactive characteristics are similar, age may serve as a useful predictor of redox status for groups of aquifers.

The observed trend in redox evolution with age is associated with an increase in denitrification progress (Fig. 3). The trend of increased denitrification at sites with older ground water likely results from longer reaction times and higher reaction rates associated with more strongly reduced water. The partial denitrification in decades-old water at all four sites is consistent with electron donor limited conditions that tend to produce low reaction rates (Ghiorse and Wilson, 1988; Chapelle, 2000).

$\mathrm{N}$-species concentration data indicate that $\mathrm{N}_{2}$ is the primary end product of $\mathrm{NO}_{3}{ }^{-}$reduction in these aquifers. Possible alternative products such as $\mathrm{NH}_{4}^{+}$and $\mathrm{NO}_{2}{ }^{-}$are seldom detected, and concentrations are below $0.02 \mathrm{mmol} \mathrm{L}^{-1}$ in all ground water samples from all sites. Nitrous oxide $\left(\mathrm{N}_{2} \mathrm{O}\right)$ can occur as an intermediate product of denitrification, but in the low $\mathrm{O}_{2}$ zones where denitrification occurs in aquifers, a large fraction of produced $\mathrm{N}_{2} \mathrm{O}$ is reduced to $\mathrm{N}_{2}$ (Well et al., 2005). This is corroborated by $\mathrm{N}_{2} \mathrm{O}$ concentrations at $\mathrm{N} 22$, where the zone of active denitrification contains only $0.1 \mu \mathrm{mol} \mathrm{L}{ }^{-1} \mathrm{~N}_{2} \mathrm{O}$ (Green et al., 2008) as compared to $351 \mu \mathrm{mol} \mathrm{L} \mathrm{L}^{-1}$ excess $\mathrm{N}_{2}$.

Stable isotope ratios and excess $\mathrm{N}_{2}$ gas concentrations indicate that some denitrification occurs at all study locations (Fig. 3). Denitrification even occurs locally at $\mathrm{MD}$, where measured $\mathrm{O}_{2}$ concentrations always exceed $3.0 \mathrm{mg} \mathrm{L}^{-1}\left(0.094 \mathrm{mmol} \mathrm{L}^{-1}\right)$ (Fig. $3 \mathrm{~d})$, indicating that individual samples may contain water from both aerobic and anaerobic zones. In each study unit, values of $\delta^{15} \mathrm{~N}\left[\mathrm{NO}_{3}^{-}\right]$and $\delta^{18} \mathrm{O}\left[\mathrm{NO}_{3}^{-}\right]$of ground water samples tend to be positively correlated (Fig. 4a). The apparent fractionation slopes $\left(\Delta \delta^{15} \mathrm{~N} / \Delta \delta^{18} \mathrm{O}\right)$ for MD (0.8), CA (2.0), and NE (1.3) are within or close to the reported range of 1 to 2 for $\mathrm{NO}_{3}^{-}$reduction processes including denitrification (Böttcher et al., 1990; Granger et al., 2004). The apparent slope at WA is 0.5 , which indicates that factors other than denitrification, such as variability of source isotopic composition, may affect the trends in stable $\mathrm{N}$ and $\mathrm{O}$ isotopes more strongly at WA than at the other study locations. In a plot of denitrification progress (the fraction of $\mathrm{N}$ occurring as excess $\mathrm{N}_{2}$ ) versus increase in $\delta^{15} \mathrm{~N}_{\mathrm{NO}_{3}}^{-}$] since recharge (Fig. 4b), most samples plot near a region bounded by Rayleigh fractionation curves with apparent fractionation factors $(\varepsilon)$ of -5 to $-20 \%$, which are similar to values reported for denitrification in ground water elsewhere (Mariotti et al., 1988; Böttcher et al., 1990; Böhlke et al., 2002). Samples with relatively small apparent fractionation effects may contain mixtures of waters with varying amounts of denitrification as a result of heterogeneous redox conditions encountered during transport, whereas some of the larger fractionation effects are closer to those expected in homogeneous systems.

Though denitrification progress reduces the concentration of $\mathrm{NO}_{3}{ }^{-}$, there is no corresponding relation between the two among the aquifer-based medians. For example, the CA aquifer has the second highest median denitrification progress, but also has the highest median concentration of $\mathrm{NO}_{3}^{-}$(Fig. 3). Similarly, the median $\mathrm{NO}_{3}{ }^{-}$concentrations for each study location do not follow the trends in median $\mathrm{O}_{2}$ and age. The lack of correspondence of median $\mathrm{NO}_{3}{ }^{-}$with median denitrification progress, $\mathrm{O}_{2}$, and age indicates that factors other
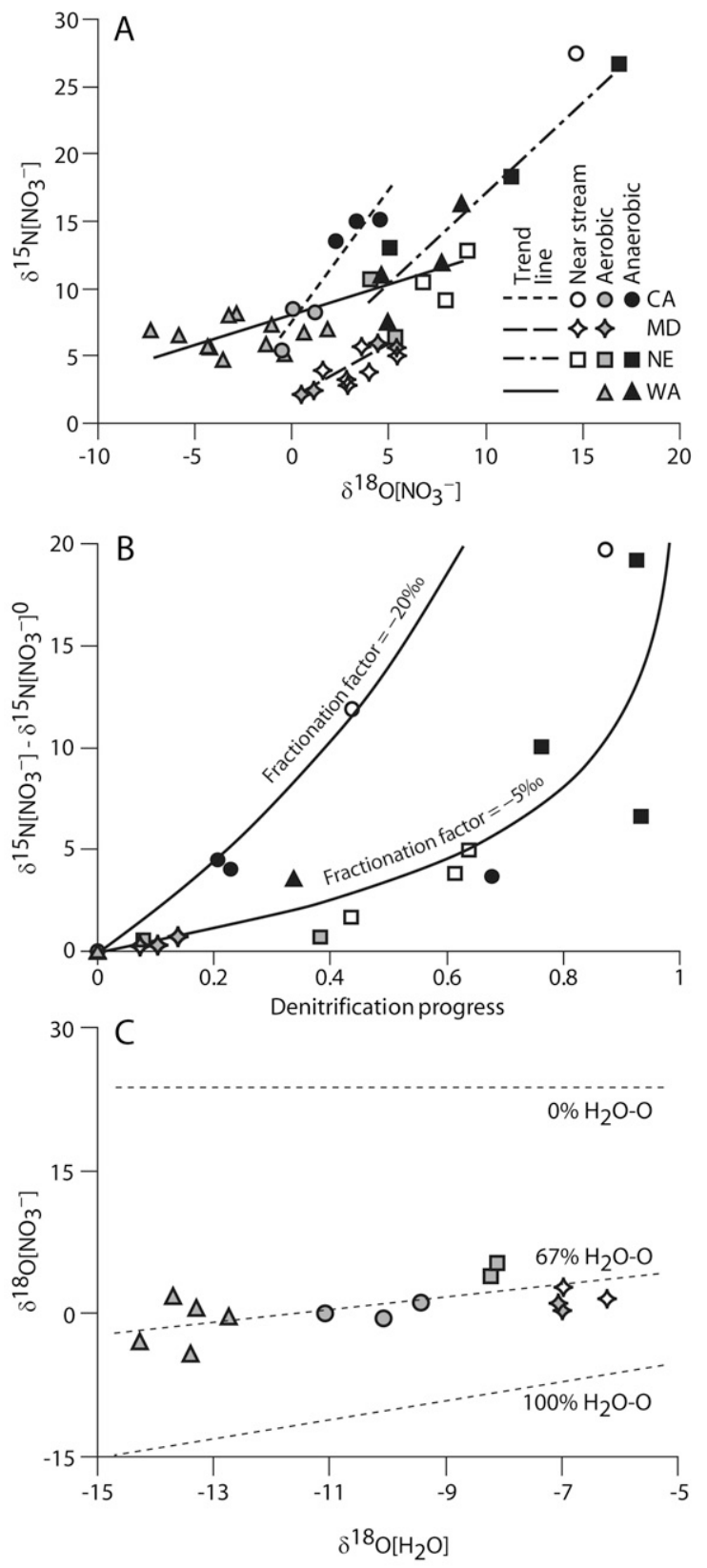

Fig. 4. Trends of stable isotopes in ground water. Values of $\delta^{15} \mathrm{~N}$ and $\delta^{18} \mathrm{O}$ are given with respect to air $\mathrm{N}_{2}$ and Vienna standard mean ocean water, respectively, in parts per thousand. (A) $\delta^{15} \mathrm{~N}\left[\mathrm{NO}_{3}{ }^{-}\right]$versus $\delta^{18} \mathrm{O}$ $\left[\mathrm{NO}_{3}{ }^{-}\right]$. Lines are least squares regressions of aerobic and anaerobic ground water data. (B) Change in $\delta^{15} \mathrm{~N}\left[\mathrm{NO}_{3}{ }^{-}\right]$during transport $\left.\left(\delta^{15} \mathrm{~N}\left[\mathrm{NO}_{3}{ }^{-}\right]-\delta^{15} \mathrm{~N}^{2} \mathrm{NO}_{3}{ }^{-}\right]^{0}\right)$ versus denitrification progress, $\xi_{\text {denit }}$. For comparison, curves show hypothetical Rayleigh fractionation based on apparent fractionation factors $(\varepsilon)$ of -5 and $-20 \%$. (C) $\delta^{18} \mathrm{O}$ values of coexisting $\mathrm{NO}_{3}{ }^{-}$and $\mathrm{H}_{2} \mathrm{O}$ in aerobic ground water and near stream samples. Dotted lines are given for reference and are defined by the isotopic composition of the major potential 0 sources during nitrification: $\delta^{18} \mathrm{O}\left[\mathrm{NO}_{3}{ }^{-}\right]=\mathrm{a} \delta^{18} \mathrm{O}\left[\mathrm{H}_{2} \mathrm{O}\right]+(1-\mathrm{a}) \delta^{18} \mathrm{O}$ [air $\mathrm{O}_{2}$, with $\mathrm{a}=0,0.67$, and 1. For (A), (B), and (C), "aerobic" samples (gray symbols) are defined by $\mathrm{O}_{2}>0.016 \mathrm{mmol} \mathrm{L}^{-1}$ and water age $<25$ yr. "Near stream" samples (unfilled symbols shown here for comparison and not included in other analyses) are ground water from near-river piezometers (Puckett et al., 2007) that show minimal interaction with surface water. 
Table 2. Statistically significant Pearson product moment correlations of selected solutes with $\mathrm{NO}_{3}{ }^{-}$at each site for $P<0.05$ (regular font) and $P<0.01$ (italic font). Each correlation value was calculated based on the collection of all available data from all wells at that study site.

\begin{tabular}{|c|c|c|c|c|}
\hline \multirow[b]{2}{*}{ Chemical property } & \multicolumn{4}{|c|}{ Study site } \\
\hline & MD & WA & $\mathrm{CA}$ & $\mathrm{NE}$ \\
\hline Excess $\mathrm{N}_{2}$ & $-\dagger$ & - & - & - \\
\hline Dissolved $\mathrm{O}_{2}$ & - & - & - & 0.72 \\
\hline$\left[\mathrm{NO}_{3}^{-}\right]^{0}$ & 0.98 & 1.00 & 0.95 & 0.86 \\
\hline Specific conductance & 0.84 & 0.42 & 0.88 & 0.65 \\
\hline $\mathrm{Ca}^{2+}$ & 0.92 & 0.62 & 0.89 & 0.48 \\
\hline $\mathrm{Mg}^{2+}$ & 0.40 & 0.35 & 0.92 & 0.66 \\
\hline $\mathrm{K}^{+}$ & 0.68 & - & 0.66 & - \\
\hline $\mathrm{Cl}^{-}$ & - & 0.46 & - & 0.64 \\
\hline $\mathrm{SO}_{4}^{2-}$ & -0.42 & - & 0.91 & - \\
\hline Dissolved organic carbon & -0.47 & - & 0.60 & 0.48 \\
\hline $\mathrm{pH}$ & -0.53 & -0.30 & -0.67 & -0.31 \\
\hline Number of samples & $9,32 \ddagger$ & 30,69 & 11,35 & 12,48 \\
\hline
\end{tabular}

than denitrification, such as loading rates, control the relative $\mathrm{NO}_{3}{ }^{-}$contamination levels in these aquifers.

\section{Variability of $\mathrm{NO}_{3}{ }^{-}$Concentrations within Aquifers}

Correlations among solutes indicate that non-reactive processes such as $\mathrm{N}$ loading rates and physical mixing control the distribution of $\mathrm{N}$ concentrations in these aquifers. Table 2 shows Pearson product moment correlations between $\mathrm{NO}_{3}{ }^{-}$and other solutes. Each correlation value is based on all available samples from an individual study site. In contrast to sites where rapid denitrification produces low $\mathrm{NO}_{3}{ }^{-}$in zones with high excess $\mathrm{N}_{2}$ and low $\mathrm{O}_{2}$ (e.g., Tesoriero et al., 2000), $\mathrm{NO}_{3}{ }^{-}$does not correlate with excess $\mathrm{N}_{2}$ at these study sites, and only correlates with $\mathrm{O}_{2}$ at the NE site (Table 2). Correlations of $\mathrm{NO}_{3}{ }^{-}$with $\left[\mathrm{NO}_{3}{ }^{-}\right]^{0}$ are 0.87 or greater at all sites, indicating that $\mathrm{NO}_{3}{ }^{-}$concentrations have not changed greatly since the time of recharge, and that substantial denitrification progress is limited to low $\left[\mathrm{NO}_{3}^{-}\right]^{0}$ samples. Nitrate frequently correlates with specific conductance, $\mathrm{Ca}^{2+}, \mathrm{Mg}^{2+}, \mathrm{K}^{+}, \mathrm{Cl}^{-}, \mathrm{SO}_{4}^{2-}$, and DOC, which are typically associated with agricultural applications such as manure, $\mathrm{N}$ fertilizers, dolomitic lime, potash, and gypsum.
At these sites, the lack of correlations that would indicate a strong influence of denitrification on $\mathrm{NO}_{3}{ }^{-}$concentrations and the abundant correlations of $\mathrm{NO}_{3}^{-}$with other agricultural chemicals indicate that the history and distribution of application rates are the primary determinant of the observed concentrations of $\mathrm{NO}_{3}^{-}$.

Results of numerical modeling support the influence of land use factors on the degree of variability of $\mathrm{NO}_{3}{ }^{-}$and other major ion concentrations at these transects. Measurements of source areas and corresponding land use (Fig. 1) show that the number of agricultural fields per source area was largest at WA, followed by CA, then $\mathrm{NE}$ and $\mathrm{MD}$ (Table 3). The variability of $\mathrm{NO}_{3}{ }^{-}$and other agricultural chemicals is also highest at WA and CA and lower at $\mathrm{MD}$ and NE (Table 3). The correspondence between variability of chemical concentration and spatial patterns of land use in the source areas likely reflects the dominant influence of agricultural practices on the broad-scale trends in concentrations. Increased variability of chemical concentrations is consistent with a greater variety of agricultural management practices on the higher number of individually managed fields in the source area. Similarly, the effects of source area variability are apparent in the correlations between agricultural chemicals. The fewest and weakest correlations exist among $\mathrm{NO}_{3}{ }^{-}$and other agricultural chemicals at WA (Table 2 ), where the widest range of crop types (Table 1) are grown in the largest number of fields per source area (Table 3). Although this analysis does not include land use history, it is consistent with the known historical changes in crop types at WA and CA and the lack of temporal changes in crop types at MD and NE, as discussed in the site descriptions. Based on available information, the percentage of agricultural land in source areas has not changed greatly along any of the well transects during the period of recharge $(<60$ yr) of ground waters sampled for this study.

Isotopic analyses of $\mathrm{NO}_{3}{ }^{-}$in undenitrified water samples from young, aerobic ground water indicate that soil $\mathrm{N}$ and mineral fertilizer constitute most modern $\mathrm{NO}_{3}{ }^{-}$sources. For each study location, the trajectories of the isotope fractionation trends originate near the $\delta^{15} \mathrm{~N}\left[\mathrm{NO}_{3}{ }^{-}\right]$and $\delta^{18} \mathrm{O}\left[\mathrm{NO}_{3}^{-}\right]$values of relatively young, undenitrified samples (Fig. 4a). For aerobic samples with more than $0.5 \mathrm{mg} \mathrm{L}^{-1} \mathrm{O}_{2}\left(0.016 \mathrm{mmol} \mathrm{L}^{-1}\right)$ (the lower threshold of Chapelle et al. (1995) is used to allow comparison among sites with no "strictly aerobic" samples) and water age $<25 \mathrm{yr}, \delta^{15} \mathrm{~N}\left[\mathrm{NO}_{3}{ }^{-}\right]$values are 6.4 to $10.7 \%$ for NE, 5.4 to $8.5 \%$ or $\mathrm{CA}, 5.2$ to $16.4 \%$ or $\mathrm{WA}$, and 2.3 to $6.1 \%$ o for $\mathrm{MD}$.

Table 3. Comparison of scales of land use in contributing areas with chemical variability. Chemical variability is quantified by the rank of interquartile ranges of the solute concentrations. Land uses in modeled source areas at MD, WA and CA are almost entirely cropland (Fig. 1).

Statistical rank $\dagger$ of interquartile range

\begin{tabular}{|c|c|c|c|c|c|c|c|c|c|c|}
\hline Study site & Avg $S A \neq$ length & Avg field length & Fields per SA§ & $\mathrm{NO}_{3}^{-}$ & $\mathrm{Ca}^{2+}$ & $\mathrm{Mg}^{2+}$ & $\mathbf{K}^{+}$ & $\mathrm{Cl}^{-}$ & $\mathrm{SO}_{4}{ }^{2-}$ & Sum of ranks \\
\hline & $-r$ & $\mathrm{~m}-$ & & & & & & & & \\
\hline NE & 52 & 418 & 0.12 & 2 & 1 & 1 & 3 & 4 & 1 & 12 \\
\hline MD & 70 & 408 & 0.17 & 1 & 2 & 2 & 1 & 1 & 2 & 9 \\
\hline CA & 155 & 317 & 0.49 & 4 & 3 & 4 & 2 & 2 & 3 & 18 \\
\hline WA & 127 & 203 & 0.62 & 3 & 4 & 3 & 4 & 3 & 4 & 21 \\
\hline
\end{tabular}

† Statistical rank in ascending order of the interquartiles of each solute for the four sites ( 1 = smallest interquartile range, $4=$ largest interquartile range).

$\ddagger \mathrm{SA}=$ source area

$\S$ Fields per SA = Average SA length/Average field length. 
Values of $8^{18} \mathrm{O}\left[\mathrm{NO}_{3}{ }^{-}\right]$in these aerobic samples are 4.1 to $5.3 \%$ o for NE, -0.54 to $1.2 \%$ o for $\mathrm{CA},-4.2$ to $0.6 \%$ o for WA, and 0.46 to $5.4 \%$ or $\mathrm{MD}$. Sources of soil $\mathrm{N}$ or mineral fertilizer typically produce $\left.\delta^{15} \mathrm{~N} \mathrm{NO}_{3}{ }^{-}\right]$of approximately -2 to $8 \%$ (Heaton, 1986; Fogg et al., 1998), which fits the range of most samples from these study locations. Higher values, especially greater than $10 \%$, may reflect modern manure sources, such as at well N21p, completed in shallow ground water below an actively grazed pasture $\left(\delta^{15} N=10.7 \% 0\right)$, and well W20p $\left(\delta^{15} N=16.4 \% 0\right)$, completed in shallow ground water at the edge of a field with manure applications. For samples with measurements of $\delta^{18} \mathrm{O}$ of water and of $\mathrm{NO}_{3}^{-}$(Fig. 4c), these measurements define a linear trend that is similar to one proposed for nitrification (microbial oxidation of $\mathrm{NH}_{4}^{+}$to $\mathrm{NO}_{3}^{-}$) in soils (Amberger and Schmidt, 1987). The negative correlations at all sites between $\mathrm{NO}_{3}{ }^{-}$and $\mathrm{pH}$ (Table 2) are consistent with production of $\mathrm{H}^{+}$ions with $\mathrm{NO}_{3}{ }^{-}$ during nitrification and transport into aquifers with limited acid neutralizing capacity, as noted previously in the vicinity of the MD site (Böhlke and Denver, 1995).

The reconstructed $\delta^{15} \mathrm{~N}\left[\mathrm{NO}_{3}^{-}\right]^{0}$ values in denitrified samples generally are similar to local measured values of $\delta^{15} \mathrm{~N}$ in bulk organic matter in surface soils (Fig. 5). The ranges of $\delta^{15} \mathrm{~N}$ for recharging $\mathrm{NO}_{3}{ }^{-}$in young, aerobic ground water and for surface soils at WA, $\mathrm{CA}$, and $\mathrm{NE}$ were slightly higher than those at $\mathrm{MD}$, and were also higher than background values observed in aquifer sediments. The elevated $\delta^{15} \mathrm{~N}$ values of surface soils and reconstructed $\mathrm{NO}_{3}^{-}$ sources at WA, CA, and NE may reflect natural differences in the soil $\mathrm{N}$ pools or may indicate a partial replacement of the reactive soil $\mathrm{N}$ pool by ${ }^{15} \mathrm{~N}$-enriched sources such as manure. Based on site average concentrations of 0.0010 to $0.0017 \mathrm{~g} \mathrm{~g}^{-1} \mathrm{~N}$, approximate bulk density of $1.8 \mathrm{~g} \mathrm{~cm}^{-3}$, and sampling depth of $30 \mathrm{~cm}$, the shallow soils at these sites contain 5400 to $9000 \mathrm{~kg} \mathrm{ha}^{-1} \mathrm{~N}$, which amounts to 38 to 92 times the corresponding annual $\mathrm{N}$ application rates at each site (Green et al., 2008). Therefore, it is feasible that agricultural applications of $\mathrm{N}$ have replaced a substantial portion of the shallow soil $\mathrm{N}$ pool within a few decades. The $\delta^{15} \mathrm{~N}$ values of aquifer sediments were relatively low and uniform among all study locations (Fig. 5) (median $\delta^{15} \mathrm{~N}$ ranging from 3.1 to $4.9 \%$ ) irrespective of redox status or agricultural practices, indicating that the $\mathrm{N}$ in these aquifer sediments is relict and has not been altered by interaction with the modern, ${ }^{15} \mathrm{~N}$-enriched $\mathrm{N}$ species.

In addition to the inter-site differences discussed above, the reconstructed $\delta^{15} \mathrm{~N}\left[\mathrm{NO}_{3}{ }^{-}\right]^{0}$ values at some of the sites may reflect changes in the dominant $\mathrm{NO}_{3}{ }^{-}$sources over time. At $\mathrm{CA}$, the reconstructed $\delta^{15} \mathrm{~N}\left[\mathrm{NO}_{3}{ }^{-}\right]^{0}$ values increase with age (Fig. 6a), consistent with a shift from manure to chemical fertilizers over the last half century. This trend matches the history inferred from aerial photographs that show that, starting 40 yr ago, the predominant agriculture in the source area began to switch from row crops, which typically receive manure, to orchards, which typically do not (Ruddy et al., 2006). Similarly, at $\mathrm{MD}, \delta^{15} \mathrm{~N}\left[\mathrm{NO}_{3}{ }^{-}\right]^{0}$ was higher for older samples (5.4 to $5.7 \%$; water age $=17 \mathrm{yr})$ compared to younger samples $(2.1$ to $2.3 \%$; water age $=2$ to $5 \mathrm{yr}$ ), reflecting the increasing use of mineral fertilizers following the cessation of chicken manure

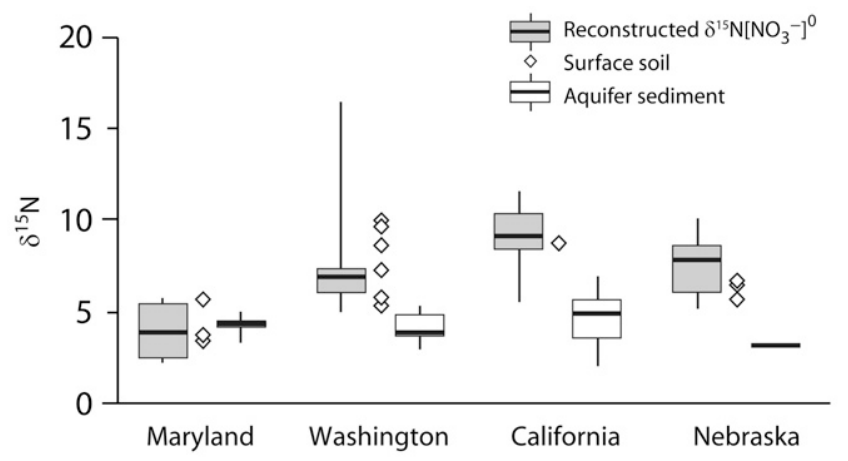

Fig. 5. Distributions of reconstructed $\delta^{15} \mathrm{~N}\left[\mathrm{NO}_{3}^{-}\right]^{0}$ of ground water (including undenitrified samples) compared to points (diamonds) showing $\delta^{15} \mathrm{~N}$ for surface soils, and box plots of $\delta^{15} \mathrm{~N}$ values for aquifer sediments at all study sites. Values of $\delta^{15} \mathrm{~N}$ are given with respect to air $\mathrm{N}_{2}$, in parts per thousand. For the box plots, error bars show the minimum and maximum values, boxes show the interquartile range, and horizontal lines show the median.

applications in the mid-1990s, as reported by the land owner.

Reconstructed $\left[\mathrm{NO}_{3}{ }^{-}\right]^{0}$ values indicate that concentrations are higher in younger ground water (travel time $<30 \mathrm{y}$ ) than in waters aged 30 to $60 \mathrm{yr}$ (Fig. 6b). These results are consistent with previous studies showing increasing concentrations in younger water due to increased fertilization (see Böhlke, 2002). More recent trends are not discernable for most sites due to a large amount of scatter; however, the data for MD are consistent with a significant decrease of $\mathrm{NO}_{3}{ }^{-}$concentration in recharging water during the last $15 \mathrm{yr}(P=0.02)$, in contrast to level or increasing concentrations reported in many agricultural areas of the United States and increasing concentrations elsewhere on the Delmarva Peninsula (Rupert, 2007).

\section{Trends in Denitrification within Aquifers}

The time required for denitrification to deplete $\mathrm{NO}_{3}^{-}$in ground water varies widely among sample points at the four study locations, as shown by the scatter of data in a plot of denitrification progress ( $\xi_{\text {denit }}$, Eq. [4]) versus age (Fig. 6c). The depletion of $\mathrm{O}_{2}$ with age is more systematic (Fig. 6d). Concentrations of $\mathrm{O}_{2}$ typically decline during the first $20 \mathrm{yr}$ after recharge and then remain below $0.15 \mathrm{mmol} \mathrm{L}^{-1}$.

At the CA site, progression of denitrification is relatively uniform across the transect, and $\xi_{\text {denit }}$ correlates positively with apparent age $(P=0.005)$ (Fig. 6c). On the basis of a least squares linear regression of the data, denitrification begins approximately $8 \mathrm{yr}$ after recharge and depletes $50 \%$ of $\mathrm{NO}_{3}^{-}$in the ground water after $31 \mathrm{yr}$ of reaction time. The timing of onset of denitrification is consistent with trends observed at other sites (Böhlke and Denver, 1995; Tesoriero et al., 2000; Puckett and Cowdery, 2002; Tesoriero et al., 2005). The sample locations with active denitrification $\left(0.0<\xi_{\text {denit }}<1.0\right)$ define a broad zone that spans $20 \mathrm{~m}$ in thickness and $1 \mathrm{~km}$ in width (Fig. 7a).

At NE, the progression of denitrification with age varies among sample locations. Some locations show higher rates within narrower portions of the aquifer than at CA. At N20 and N22, denitrification progresses rapidly in a zone between the water table and the shallowest sample location (Fig. 7b). Values of $\left.\delta^{15} \mathrm{~N}_{\mathrm{NO}_{3}}^{-}\right]$and 

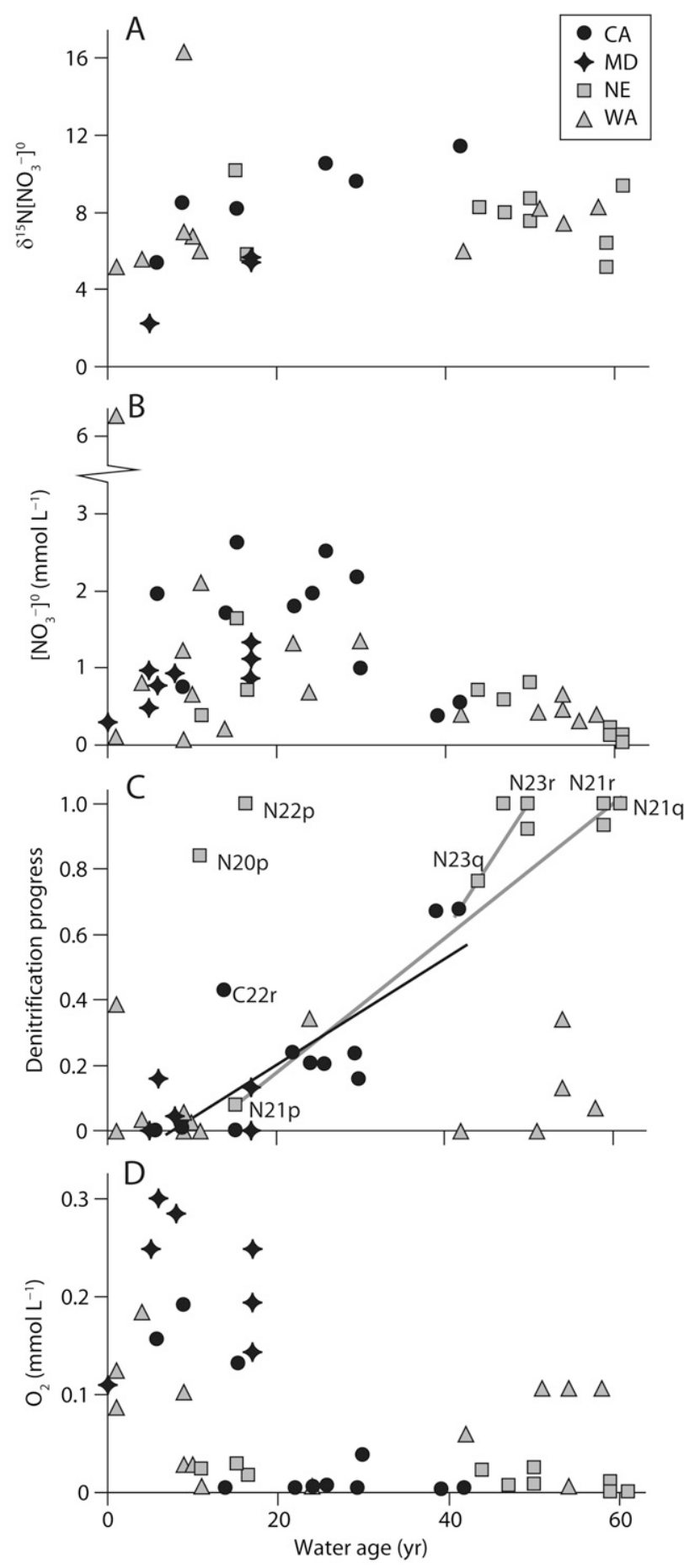

Fig. 6. (A) Average water age with mixing compared to reconstructed $\left.\delta^{15} \mathrm{~N}^{2} \mathrm{NO}_{3}{ }^{-}\right]^{0}$. Values of $\delta^{15} \mathrm{~N}$ are given with respect to air $\mathrm{N}_{2^{\prime}}$ in parts per thousand. (B) Average water age with mixing compared to $\left[\mathrm{NO}_{3}^{-}\right]^{0}$. (C) Average water age with mixing compared to denitrification progress, $\xi_{\text {denit }}$. Lines are least squares regressions to the data from the California transect, and the N23 and N21 well clusters at Nebraska. (D) Average water age with mixing versus dissolved $\mathrm{O}_{2}$.

$\delta^{18} \mathrm{O}\left[\mathrm{NO}_{3}{ }^{-}\right]$in the unsaturated zone above $\mathrm{N} 22 \mathrm{p}$ are comparable to source isotopic compositions (Green et al., 2008), suggesting that the onset of denitrification is below the top of the capillary fringe. Complete denitrification of source water appears to occur within a 3.5-m-thick zone between the water table and N22p (Fig. 7b). Similarly, the denitrification progress and water age at $\mathrm{N} 20 \mathrm{p}$ imply denitrification of $84 \%$ of source $\mathrm{NO}_{3}{ }^{-}$within $11 \mathrm{yr}$ of travel time. In contrast, at N23 and N21, low concentrations of excess $\mathrm{N}_{2}$ relative to $\mathrm{NO}_{3}{ }^{-}$are consistent with more gradual denitrification. Across all depths at N23, the denitrification progress increases with age such that $50 \%$ denitrification occurs after 13 yr of reaction time (Fig. 6c). At N21, apparent ages and N species concentrations imply rates of $50 \%$ denitrification in less than 24 yr. Overall, the data from NE indicate $50 \%$ denitrification in $<8$ to $25 \mathrm{yr}$, although, as previously noted, high denitrification progress is limited to low $\left[\mathrm{NO}_{3}^{-}\right]^{0}$ samples, and it is not evident that the same progress will occur for higher $\left[\mathrm{NO}_{3}^{-}\right]^{0}$ waters. The zone of active denitrification ranges in thickness from $<3.5 \mathrm{~m}$ at $\mathrm{N} 22$ to 6.2 to $10.2 \mathrm{~m}$ at N23 (Fig. 7b). The variation in rates along the $\mathrm{NE}$ transect may result in part from the unusual orientation of the transect relative to the regional ground water gradient (Fig. 1). NE is the only study location with modeled source areas in riparian zones, which often have relatively low $\left[\mathrm{NO}_{3}^{-}\right]^{0}$ and high rates of ground water denitrification (e.g., Vidon and Hill, 2004).

At WA and MD, denitrification appears to be limited in extent due to aerobic conditions. In samples from both study sites, denitrification progress was less than 0.5 (Fig. 6c) and $\mathrm{O}_{2}$ was frequently greater than $0.05 \mathrm{mmol} \mathrm{L}^{-1}$ (Fig. 6d). At WA, zones of active denitrification were disconnected and irregular. For example, at W21 and W24 there was no evidence of denitrification at any depth. At W31 and W32, excess $\mathrm{N}_{2}$ was detected in shallow wells but not in deeper ground water. Denitrification rates comparable to those at CA may occur locally, for example in the vicinity of W32p and W23q, but the overall rate of denitrification at this site is low. Three-quarters of the samples have denitrification progress less than 0.13 , and most of the oldest ground water samples (apparent age $>50 \mathrm{yr}$ ) have $\mathrm{O}_{2}$ greater than $0.1 \mathrm{mmol} \mathrm{L}^{-1}$ and show no evidence of denitrification. The variability of denitrification at WA likely reflects the large variability of agricultural land use within the source area, and intensive application of manure at some locations. At MD also, aerobic conditions likely limit the zone of active denitrification, which was encountered only at M20. At this location, denitrification progress was 0.10 at the shallowest well M20p (no age estimates available), 0.16 over 6 yr travel time to the middle well M20q, and 0.14 over $17 \mathrm{yr}$ travel time to the deepest well, M20r.

The combined data from this multi-site study and previous studies using similar methods indicate that many of the denitrification rates reported in the literature may be skewed high relative to the range of rates in surficial aquifers like the ones considered here. At these study locations, zero-order rates as calculated by the excess $\mathrm{N}_{2}$ divided by the water age were 0 to $0.03 \mu \mathrm{mol} \mathrm{N}$ $\mathrm{L}^{-1} \mathrm{~d}^{-1}$ for WA, 0 to $0.06 \mu \mathrm{mol} \mathrm{N} \mathrm{L}{ }^{-1} \mathrm{~d}^{-1}$ for MD, 0 to 0.14 $\mu \mathrm{mol} \mathrm{N} \mathrm{L}{ }^{-1} \mathrm{~d}^{-1}$ for CA, and 0 to $0.12 \mu \mathrm{mol} \mathrm{N} \mathrm{L} \mathrm{N}^{-1} \mathrm{~d}^{-1}$ for $\mathrm{NE}$. Figure 8 shows maximum zero-order in situ denitrification rates from previous studies. The references were obtained primarily from tables in Korom (1992) and Groffman et al. (2006) along with several more recent studies. The reported maximum denitrification rates summarized in Fig. 8 range from less than $10^{-2}$ 


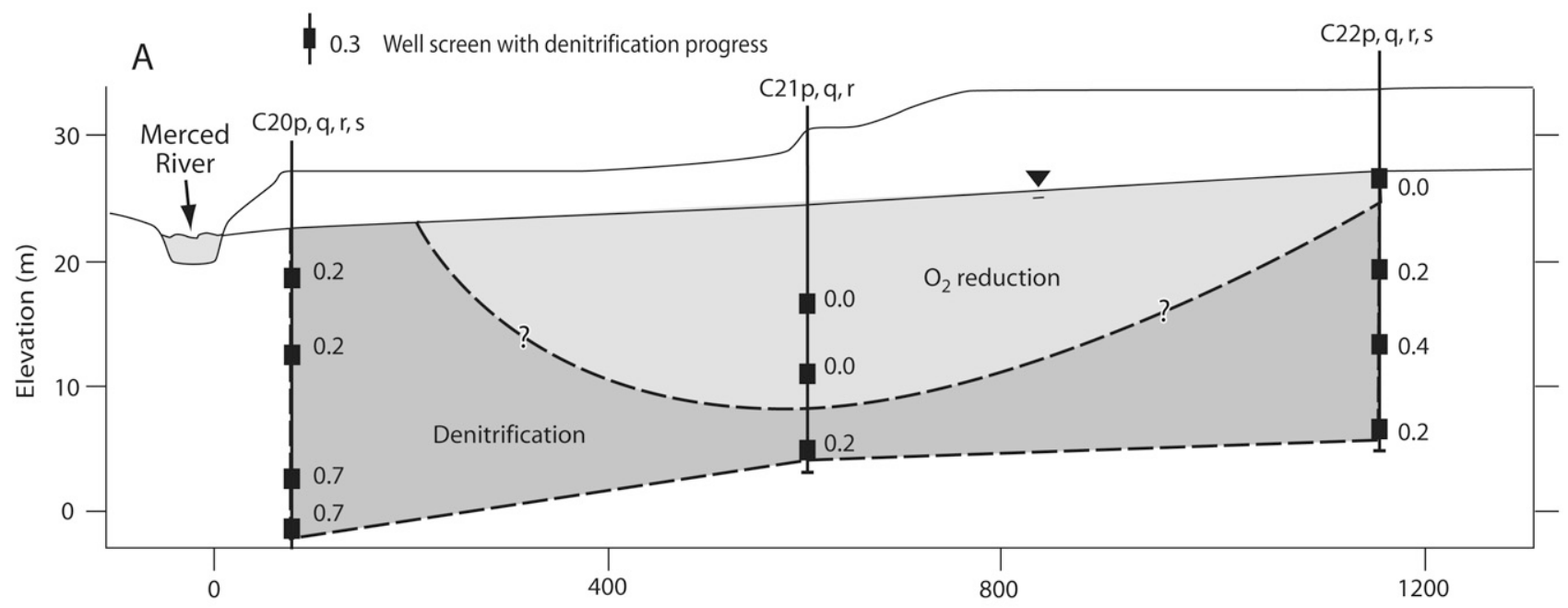

B

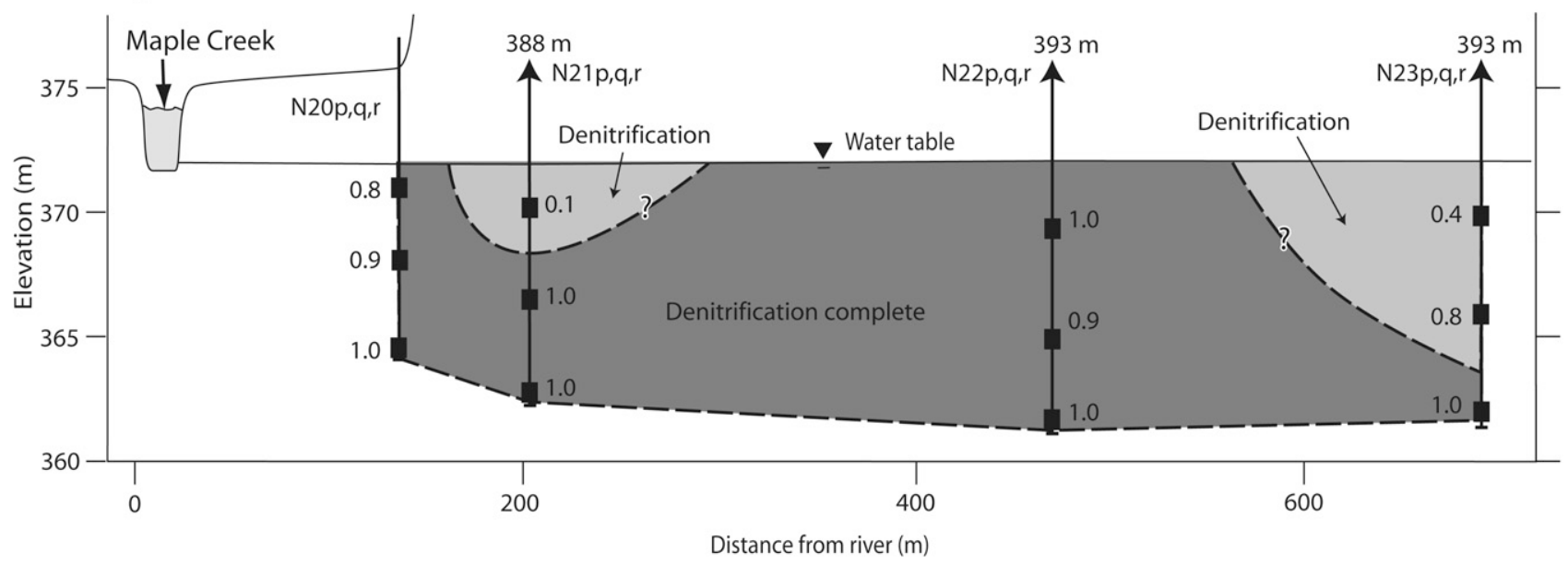

Fig. 7. Cross sections of well locations, river locations, and denitrification progress for (A) California and (B) Nebraska. The light gray shading shows approximate zones of oxygen reduction below the water table, the moderate gray shading shows the approximate zones of denitrification, and the dark gray shading shows the zones of complete denitrification.

to greater than $10^{4} \mu \mathrm{mol} \mathrm{N} \mathrm{L}{ }^{-1} \mathrm{~d}^{-1}$. Even lower rates $\left(10^{-5}\right.$ to $10^{-4} \mu \mathrm{mol} \mathrm{N} \mathrm{L}^{-1} \mathrm{~d}^{-1}$ ) have been reported from aquifers with ground water residence times that are thousands of years long as determined by ${ }^{14} \mathrm{C}$ dating (e.g., Vogel et al., 1981; McMahon et al., 2004). Rates tend to be highest for studies using injection of solutes into aquifers, and rates are intermediate for estimates based on naturally occurring gradients of $\mathrm{NO}_{3}{ }^{-}$concentrations. The lowest rates are reported consistently by studies, such as this one, that analyze naturally occurring gradients of excess $\mathrm{N}_{2}$ concentrations. Moderate rates for $\mathrm{N}_{2}$ gradient methods are for studies in unusual redox settings, such as below a dairy waste lagoon (Singleton et al., 2007) and where the method is applied to a selected portion of the zone of active denitrification (Tesoriero et al., 2000). For injectionbased studies, the high rates commonly reflect selection of sites or portions of aquifers with known or suspected denitrification (e.g., Trudell et al., 1986; van Beek and van Puffelen, 1987; Starr and Gillham, 1989; Korom, 1991; Korom et al., 2005). In the studies of $\mathrm{NO}_{3}^{-}$gradients, estimated rates may be elevated due to historical trends that interfere with interpretation of $\mathrm{NO}_{3}{ }^{-}$gradients or due to selection of sites with known denitrification. In a study employing all three methods, Tesoriero et al. (2000) reported three rates that correspond to the pattern observed in the literature: the highest rates were reported for a reactive zone tested by injection of $\mathrm{NO}_{3}{ }^{-}$, intermediate rates were based on $\mathrm{NO}_{3}{ }^{-}$gradient, and the lowest rate was based on $\mathrm{N}_{2}$ gradients at the same location (Fig. 8).

Higher rates of denitrification in riparian zones relative to upgradient locations have been observed at some sites (Hill, 1996), but do not occur along the limited extents of most of these well transects. At CA, NE, and WA, the most elevated rates did not occur in wells closest to the river. At CA, the rates of denitrification progress $\left(\xi_{\text {denit }}\right.$ divided by travel time) are highest at C22r in the most upgradient well cluster (Fig. 6c), where the highest zero-order rates also occur. At NE, the rates of denitrification progress appear similar for N20, adjacent to the river, and N22, distant from the river (Fig. 6c), and the highest zero-order rates occur at N22. The highest zero-order rates at WA occurred at W23q, over a $\mathrm{km}$ from the riparian zone. MD was the only site in which the well closest to the stream (M20) had the highest rate of denitrification progress and zero-order production of excess $\mathrm{N}_{2}$. 


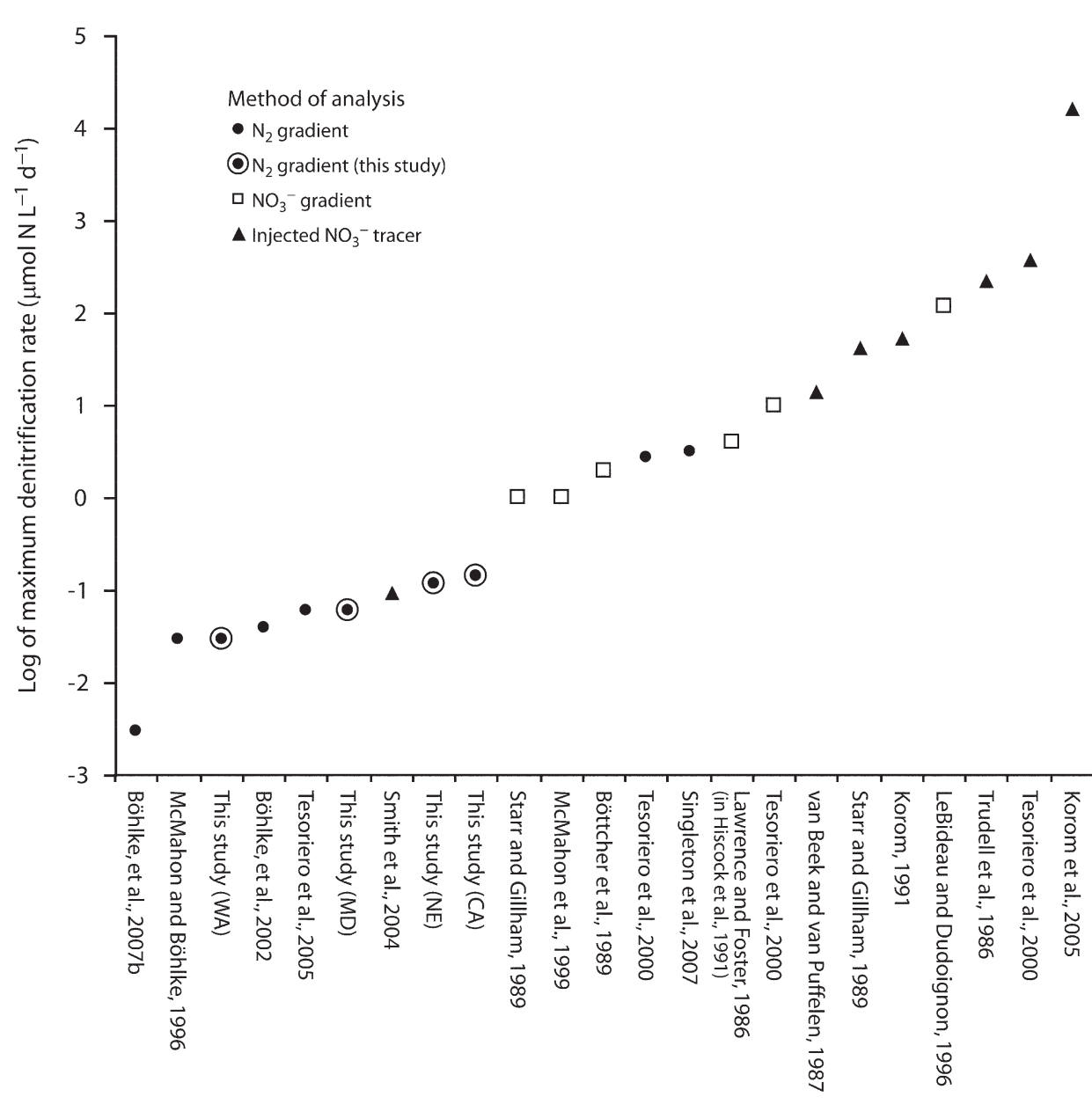

Fig. 8. Maximum, in situ, zero-order denitrification rates from previous studies and from this study, sorted from lowest to highest values. The rate from Singleton et al. (2007) is inferred from excess $N_{2}$ and apparent age values from well W-16.

\section{Electron Donor Controls on Reduction of $\mathrm{NO}_{3}{ }^{-}$and $\mathrm{O}_{2}$}

Dissolved and solid phase chemical data indicate that electron donors originating in recharge water are minor contributors to denitrification and other redox reactions at these four study locations. Based on commonly assumed electron-balance reaction stoichiometries during denitrification, the molar ratios of $\mathrm{NO}_{3}{ }^{-}$reduced to electron donors oxidized are 0.8 for organic $\mathrm{C}(0), 2.8$ for sulfide in $\mathrm{FeS}_{2}$, and 0.2 for $\mathrm{Fe}(\mathrm{II})$ (Böhlke, 2002). Aqueous phase $\mathrm{Fe}(\mathrm{II})$ and sulfide are not present in sufficient quantities in recharging water to account for the observed losses of $\mathrm{NO}_{3}{ }^{-}$or, further, the observed loss of $\mathrm{O}_{2}$. In shallow ground water, $\mathrm{Fe}(\mathrm{II})$ was never greater than $0.0005 \mathrm{mmol} \mathrm{L}^{-1}$, and sulfide was never greater than $0.042 \mathrm{mmol} \mathrm{L}^{-1}$ in any sample, as compared to typical concentrations of 0.5 to $1 \mathrm{mmol} \mathrm{L}^{-1} \mathrm{NO}_{3}{ }^{-}$and $0.2 \mathrm{mmol} \mathrm{L}^{-1} \mathrm{O}_{2}$ in young, shallow samples. At the maximum detected concentrations, the dissolved $\mathrm{Fe}(\mathrm{II})$ and sulfide could account for denitrification of 0.0001 and $0.07 \mathrm{mmol} \mathrm{L}^{-1} \mathrm{NO}_{3}^{-}$, respectively. Dissolved organic carbon is more abundant, and data at the NE site are consistent with DOC reactions in recharging water. At the NE site, DOC decreases linearly with water age $(P=0.04)$ and the specific ultraviolet absorbance (a potential indicator of the reactivity of DOC (Weishaar et al., 2003)) also tends to decrease linearly with water age $(P=0.02)$. The decrease in dissolved $\mathrm{O}_{2}$ is associated with a decrease in DOC $(P=0.002)$ with a least squares regression slope of 1.5 moles $\mathrm{O}_{2}$ per 1 mole DOC. These trends are consistent with oxidation of the more labile fraction of DOC during transport, or could possibly result from changes in quantity and quality of DOC relating to historical changes in the types of DOC sources. The change in DOC concentration from the highest to lowest concentrations at $\mathrm{NE}$ is $0.47 \mathrm{mmol} \mathrm{L}^{-1}$. Based on a simple electron balance $\left(\mathrm{O}_{2} / \mathrm{C}(0)\right.$ $=1$ ), this amount of DOC could reduce all $\mathrm{O}_{2}$ at its highest concentration $\left(0.05 \mathrm{mmol} \mathrm{L}^{-1}\right)$ in addition to $0.34 \mathrm{mmol} \mathrm{L}^{-1} \mathrm{NO}_{3}{ }^{-}$. The 0.17 mmol L ${ }^{-1}$ excess $\mathrm{N}_{2}$ produced by this reaction, however, could not fully account for the 0.3 to 0.4 mmol L ${ }^{-1}$ excess $\mathrm{N}_{2}$ at many wells, indicating that other electron donors contribute to denitrification. At the other sites, recharging DOC does not contribute substantially to reduction of $\mathrm{O}_{2}$ or $\mathrm{NO}_{3}{ }^{-}$. Median DOC concentrations in recharging ground water are low $(0.04 \mathrm{mmol}$ $\mathrm{L}^{-1}$ at $\mathrm{MD}, 0.16 \mathrm{mmol} \mathrm{L}^{-1}$ at WA, and $0.10 \mathrm{mmol} \mathrm{L}^{-1}$ at $\mathrm{CA}$ ) and are nearly identical to the median concentrations in $\mathrm{O}_{2}$ depleted $\left(<1.0 \mathrm{mmol} \mathrm{L}^{-1} \mathrm{O}_{2}\right)$ ground water at those sites. In general, recharging electron donors are insufficient to account for losses of $\mathrm{O}_{2}$ and $\mathrm{NO}_{3}^{-}$at the aquifer scale, and relict, solid phase materials in the aquifer are likely the primary sources of electron donors for $\mathrm{O}_{2}$ reduction and denitrification.

Concentrations of solid phase electron donors are low at the four study locations. Aquifer sediments at WA contained the highest median concentrations of $\mathrm{Fe}(\mathrm{II})\left(1400 \mu \mathrm{g} \mathrm{g}^{-1}\right)$ and acid volatile sulfides (AVS) + pyrite-S (median $=3.9 \mu \mathrm{g} \mathrm{g}^{-1}$ ) (Fig. 9). Elsewhere, median $\mathrm{Fe}(\mathrm{II})$ ranged from 46 to $670 \mathrm{\mu g} \mathrm{g}^{-1}$ and median AVS + pyrite-S ranged from 0.1 to $1.6 \mu \mathrm{g} \mathrm{g}^{-1}$. The highest concentrations of organic C occurred at MD (median $=900 \mu \mathrm{g} \mathrm{g}^{-1}$ ) with medians of approximately $500 \mathrm{\mu g} \mathrm{g}^{-1}$ at the other study sites. Interestingly, the aquifers with more denitrification (CA and NE) tended to have lower organic $\mathrm{C}$ content. Nevertheless, concentrations of solid phase electron donors are sufficient to account for the losses of $\mathrm{O}_{2}$ and $\mathrm{NO}_{3}{ }^{-}$at these sites. For example, assuming a porosity of 0.33 and bulk density of $1.8 \mathrm{~g} \mathrm{~cm}^{-3}$, the aquifer material containing $500 \mathrm{\mu g} \mathrm{g}^{-1} \mathrm{Fe}(\mathrm{II})$ could reduce $0.16 \mathrm{mmol} \mathrm{L}^{-1}$ of ambient $\mathrm{O}_{2}$ and $9.7 \mathrm{mmol} \mathrm{L}^{-1} \mathrm{NO}_{3}^{-}$(see Trudell et al., 1986). Likewise the AVS + pyrite-S concentrations of $50 \mu \mathrm{g} \mathrm{g}^{-1}$ could reduce ambient $\mathrm{O}_{2}$ plus $6.7 \mathrm{mmol} \mathrm{L}^{-1} \mathrm{NO}_{3}{ }^{-}$. For organic carbon, $1000 \mu \mathrm{g} \mathrm{g}^{-1}$ could 


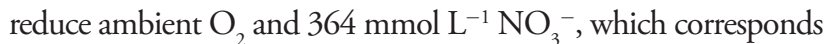
to tens to hundreds of pore volumes with the maximum observed $\mathrm{NO}_{3}{ }^{-}$concentrations at these sites. Although the total concentrations of solid phase electron donors clearly indicate the potential for reduction of $\mathrm{O}_{2}$ and $\mathrm{NO}_{3}^{-}$, the quantities of reactive electron donors are uncertain because a substantial portion may be inert or physically inaccessible to denitrifying microbes (Korom, 1992; Puckett and Cowdery, 2002). The electron donor concentrations are relatively low compared to published values for other shallow aquifers with comparable rates of denitrification. For example, Böhlke et al. (2002) reported 100 to $200 \mu \mathrm{g} \mathrm{g}^{-1}$ of pyrite-S and 1000 to $2300 \mu \mathrm{g} \mathrm{g}^{-1}$ organic $\mathrm{C}$ in the recharge area of a glacial outwash sand aquifer in Minnesota where denitrification with rates on the order of $0.04 \mu \mathrm{mol} \mathrm{N} \mathrm{L}^{-1} \mathrm{~d}^{-1}$ were related in part to pyrite oxidation. Larger reservoirs of $\mathrm{FeS}_{2}$ have been reported in denitrifying aquifers elsewhere (e.g., Postma et al., 1991; Robertson et al., 1996; Böhlke et al., 2007).

The overall abundance of solid phase electron donors (Fig. 9) does not relate in an obvious fashion to the extent of denitrification observed at each site location (Fig. 3d). On a sampleby-sample basis, MD is the only site where the distribution of solid phase electron donors appears to reflect the ground water redox status. The highest concentrations of organic $\mathrm{C}, \mathrm{Fe}(\mathrm{II})$, and AVS + pyrite were found at M20p, M20q, and M20r, which also yielded ground water with the lowest $\mathrm{O}_{2}$ and highest excess $\mathrm{N}_{2}$. Goethite was detected by $\mathrm{X}$-ray diffraction only at this location and not elsewhere at the transect, indicating that reduced iron may be oxidized in the surrounding sediments.

The results from the four sites indicate that solid phase electron donors strongly contribute to $\mathrm{O}_{2}$ reduction and denitrification, as has been observed elsewhere. If current $\mathrm{N}$ fluxes to shallow ground water persist, the continued consumption of a finite pool of relict solid phase electron donors by recharging $\mathrm{O}_{2}$ and $\mathrm{NO}_{3}{ }^{-}$will eventually deplete electron donors and reduce the rates of denitrification. The time required to produce a substantial effect is difficult to predict. Although the concentrations of electron donors in sediments are sufficient to reduce many pore volumes of recharge water, much of the electron donor pool may be inert over time scales of interest for contaminant transport. To address questions about the long-term prospects for denitrification, additional work is needed to quantify the reactivity of the relict electron donors.

\section{Conclusions}

Based on estimated denitrification rates from this study and similar studies, high denitrification rates often reported in the literature are not representative of conditions in shallow, agricultural aquifers such as these. This is consistent with the recent results from a survey of 15 principal aquifer systems across the United States that showed that $\mathrm{O}_{2}$ reduction is the dominant redox process in most aquifers (McMahon and Chapelle, 2007). Because croplands in the United States are a major source of $\mathrm{NO}_{3}{ }^{-}$flux to ground water, the prevalence of oxic waters and low denitrification rates in decades-old ground water indicates that current fertilizer management practices in the United States will affect regional $\mathrm{N}$ budgets and ground water
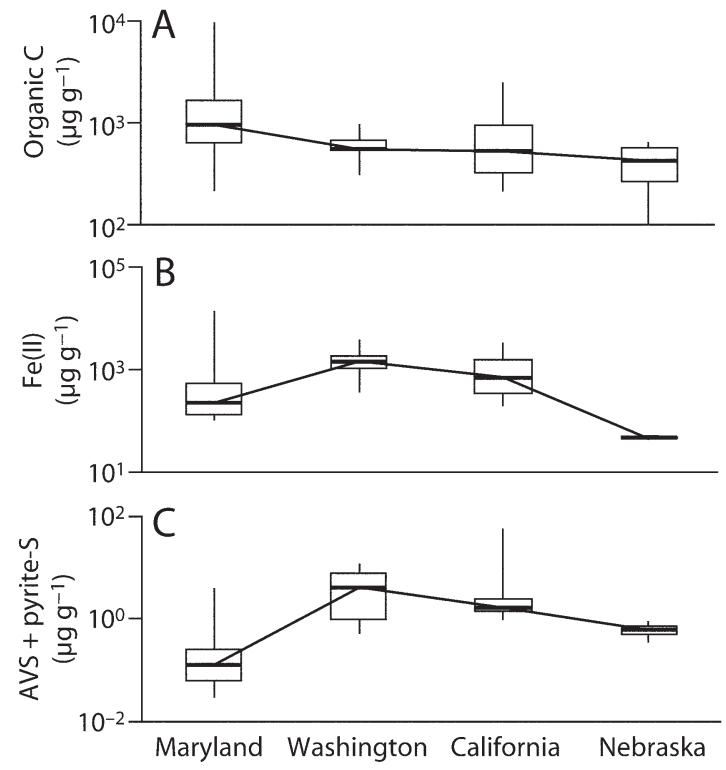

Fig. 9. Distributions of solid phase constituents including (A) organic C, (B) $\mathrm{Fe}(\mathrm{II})$, and (C) acid-volatile sulfides (AVS) + pyrite-S. Error bars show the minimum and maximum values, boxes show the interquartile range, and horizontal lines inside the boxes show the median.

quality on the time scale of decades to centuries.

Results show that denitrification does not strongly affect the distribution of $\mathrm{NO}_{3}{ }^{-}$throughout these four study transects. At all sites, $\mathrm{NO}_{3}{ }^{-}$exhibits strong correlations with other agricultural chemicals, indicating that the $\mathrm{NO}_{3}{ }^{-}$originates from agricultural sources, and that the application history mainly controls the distribution of $\mathrm{NO}_{3}{ }^{-}$mass in the aquifers. Numerical models of transect source areas show that the variability in observed concentrations for each study site relates to the scale of agricultural land use. More uniform land use within a source area corresponds to more uniform concentrations across the sample transect, further indicating that agricultural practices influence the spatial and temporal trends of $\mathrm{NO}_{3}{ }^{-}$.

Reconstructed isotopic source signatures and analyses of solid phase isotopes revealed information about the sources of $\mathrm{NO}_{3}{ }^{-}$contamination at these sites. Decreased values of reconstructed $\delta^{15} \mathrm{~N}\left[\mathrm{NO}_{3}^{-}\right]^{0}$ in relatively young waters reflect an overall shift away from ${ }^{15} \mathrm{~N}$-enriched sources, such as manure, and toward ${ }^{15} \mathrm{~N}$-depleted sources, such as chemical fertilizers. Similarly, higher values of $\delta^{15} \mathrm{~N}$ of surface soils at WA, CA, and NE, as compared to MD, may reflect higher applications of ${ }^{15} \mathrm{~N}$-enriched sources such as manure.

Trends in excess $\mathrm{N}_{2}, \mathrm{O}_{2}$, and isotopic fractionation indicate that some degree of denitrification occurs at all sites. All of the sites appear to be electron donor limited, however, and denitrification proceeds at the expense of relict electron donors in aquifer material. High values of fractional denitrification progress are limited to samples with initially low concentrations of $\mathrm{NO}_{3}^{-}$, and it remains unclear whether the current reaction rates will persist as recently recharged waters with high $\mathrm{NO}_{3}{ }^{-}$encounter and deplete the labile relict electron donors. Although all these areas of ground water recharge below agricultural fields show some denitrification, rates tend to vary within each site, and are often 
too slow to substantially mitigate $\mathrm{NO}_{3}{ }^{-}$contamination before transport to discharge zones or deeper ground water receptors.

\section{Acknowledgments}

This study was conducted as part of the USGS National Water Quality Assessment Program and benefited from the work of many individuals involved in planning and execution. The authors thank Paul Capel for help with planning and oversight, and James LaBaugh, Jim Tesoriero, and three anonymous reviewers for helpful comments and suggestions for improving the original manuscript. The use of trade names in this paper is for identification purposes only and does not constitute endorsement by the USGS.

\section{References}

Alexander, R.A., and R.A. Smith. 1990. County-level estimates of nitrogen and phosphorus fertilizer use in the United States, 1945-1985. OpenFile Rep. USGS. 90-130. USGS, Washington, DC.

Amberger, A., and H.L. Schmidt. 1987. The natural isotope content of nitrate as an indicator of its origin. Geochim. Cosmochim. Acta 51:2699-2705.

Bicknell, B.R., J.C. Imhoff, J.L. Kittle, A.S. Donigian, and R.C. Johanson. 1997. Hydrological simulation program-Fortran: User's manual for version 11. EPA/600/R-97/080. USEPA, National Exposure Research Lab., Athens, Ga.

Blicher-Mathiesen, G., G.W. McCarty, and L.P. Nielsen. 1998. Denitrification and degassing in groundwater estimated from dinitrogen and argon. J. Hydrol. 208:16-24.

Böhlke, J.K. 2002. Groundwater recharge and agricultural contamination. Hydrogeol. J. 10:153-179 [erratum 10:438-439].

Böhlke, J.K., and T.B. Coplen. 1995. Interlaboratory comparison of reference materials for nitrogen-isotope-ratio measurements. In Reference and intercomparison materials for stable isotopes of light elements. IAEATECDOC-825. International Atomic Energy Agency, Vienna.

Böhlke, J.K., and J.M. Denver. 1995. Combined use of ground water dating, chemical, and isotopic analyses to resolve the history and fate of nitrate contamination in two agricultural watersheds, Atlantic coastal plain, Maryland. Water Resour. Res. 31:2319-2339.

Böhlke, J.K., S.J. Mroczkowski, and T.B. Coplen. 2003. Oxygen isotopes in nitrate: New reference materials For 18O:17O:16O measurements and observations on nitrate-water equilibration. Rapid Commun. Mass Spectrom. 17:1835-1846.

Böhlke, J.K., M.E. O'Connell, and K.L. Prestegaard. 2007. Ground water stratification and delivery of nitrate to an incised stream in varying flow conditions. J. Environ. Qual. 36:664-680.

Böhlke, J.K., R. Wanty, M. Tuttle, G. Delin, and M. Landon. 2002. Denitrification in the recharge area and discharge area of a transient agricultural nitrate plume in a glacial outwash sand aquifer, Minnesota. Water Resour. Res. 38:1105 doi:10.1029/2001WR000663.

Böttcher, J., O. Strebel, S. Voerkelius, and H.-L. Schmidt. 1990. Using isotope fractionation of nitrate-nitrogen and nitrate-oxygen for evaluation of microbial denitrification in a sandy aquifer. J. Hydrol. 114:413-424.

Busenberg, E., and L.N. Plummer. 1992. Use of chlorofluorocarbons $\left(\mathrm{CCl}_{3} \mathrm{~F}\right.$ and $\left.\mathrm{CCl}_{2} \mathrm{~F}_{2}\right)$ as hydrologic tracers and age-dating tools: The alluvium and terrace system of central Oklahoma. Water Resour. Res. 28:2257-2283.

Busenberg, E., and L.N. Plummer. 2000. Dating young ground water with sulfur hexafluoride: Natural and anthropogenic sources of sulfur hexafluoride. Water Resour. Res. 36:3011-3030.

Capel, P.D. 2008. National, holistic, watershed-scale approach to understand the sources, transport, and fate of agricultural chemicals. J. Environ. Qual. 37:983-993.

Casciotti, K.L., D.M. Sigman, A.G. Hastings, J.K. Böhlke, and A. Hilkert. 2002. Measurement of the oxygen isotopic composition of nitrate in seawater and freshwater using the denitrifier method. Anal. Chem. 74:4905-4912.

Champ, D.R., J. Gulens, and R.E. Jackson. 1979. Oxidation-reduction sequences in ground water flow systems. Can. J. Earth Sci. 16:12-23.

Chapelle, F.H. 2000. The significance of microbial processes in hydrogeology and geochemistry. Hydrogeol. J. 8:41-46.
Chapelle, F.H., P.B. McMahon, N.M. Dubrovsky, R.F. Fujii, E.T. Oaksford, and D.A. Vroblesky. 1995. Deducing the distribution of terminal electron-accepting processes in hydrologically diverse ground water systems. Water Resour. Res. 31:359-371.

Commission on Geosciences. Environment, and Resources. 2000. Natural attenuation for groundwater remediation. National Academy Press, Washington, DC

Cook, P.G., and J.K. Böhlke. 2000. Determining timescales for groundwater flow and solute transport. p. 1-30. In P.G. Cook and A.L. Herczeg (ed.) Environmental tracers in subsurface hydrology. Kluwer Academic Publ., Boston, MA.

Coplen, T.B., J.K. Böhlke, and K. Casciotti. 2004. Using dual-bacterial denitrification to improve $\delta^{15} \mathrm{~N}$ determinations of nitrates containing mass-independent ${ }^{17} \mathrm{O}$. Rapid Commun. Mass Spectrom. 18:245-250.

Fisher, L.H., and R.W. Healy. 2008. Water movement within the unsaturated zone in four agricultural areas of the United States. J. Environ. Qual. 37:1051-1063.

Fogg, G.E., D.E. Rolston, D.L. Decker, D.T. Louie, and M.E. Grismer. 1998. Spatial variation in nitrogen isotope values beneath nitrate contamination sources. Ground Water 36:418-426.

Frind, E.O., W.H.M. Duynisveld, O. Strebel, and J. Boettcher. 1990. Modeling of multicomponent transport with microbial transformation in groundwater: The Fuhrberg case. Water Resour. Res. 26:1707-1719.

Ghiorse, W.C., and J.T. Wilson. 1988. Microbial ecology of the terrestrial subsurface. Adv. Appl. Microbiol. 33:107-172.

Granger, J., D.M. Sigman, J.A. Needoba, and P.J. Harrison. 2004. Coupled nitrogen and oxygen isotope fractionation of nitrate during assimilation by cultures of marine phytoplankton. Limnol. Oceanogr. 49:1763-1773.

Green, C.T., L.H. Fisher, and B.A. Bekins. 2008. Nitrogen fluxes through unsaturated zones in five agricultural settings across the United States. J. Environ. Qual. 37:1073-1085.

Groffman, P.M., M.A. Altabet, J.K. Böhlke, K. Butterbach-Bahl, M.B. David, M.K. Firestone, A.E. Giblin, T.M. Kana, L.P. Nielsen, and M.A. Voytek. 2006. Methods for measuring denitrification: Diverse approaches to a difficult problem. Ecol. Appl. 16:2091-2122.

Hallberg, G.R., and D.R. Keeney. 1993. Nitrate. p. 297-322. In W.M. Alley (ed.) Regional ground water quality. Van Nostrand Reinhold, New York.

Harbaugh, A.W., E.R. Banta, M.C. Hill, and M.G. McDonald. 2000. MODFLOW-2000, the U.S. Geological Survey modular ground water model-User guide to modularization concepts and the ground water flow process. Open-File Rep. USGS. 00-92. USGS, Washington, DC.

Heaton, T.H.E. 1986. Isotopic studies of nitrogen pollution in the hydrosphere and atmosphere-A review. Chem. Geol. 59:87-102.

Heaton, T.H.E., and J.C. Vogel. 1981. "Excess air" in ground water. J. Hydrol. 50:201-216.

Hill, A.R. 1996. Nitrate removal in stream riparian zones. J. Environ. Qual. 25:743-755.

Hiscock, K.M., J.W. Lloyd, and D.N. Lerner. 1991. Review of natural and artificial denitrification of groundwater. Water Res. 25:1099-1111.

Howarth, R.W., and R. Marino. 2006. Nitrogen as the limiting nutrient for eutrophication in coastal marine ecosystems: Evolving views over three decades. Limnol. Oceanogr. 51:364-376.

Kölle, W., O. Strebel, and J. Böttcher. 1985. Formation of sulfate by microbial denitrification in a reducing aquifer. Water Supply 3:35-40.

Korom, S.F. 1991. Denitrification in the unconsolidated deposits of the Heber Valley Aquifer. Ph.D. thesis. Utah State Univ., Logan, UT.

Korom, S.F. 1992. Natural denitrification in the saturated zone: A review. Water Resour. Res. 28:1657-1668.

Korom, S.F., A.J. Schlag, W.M. Schuh, and A.K. Schlag. 2005. In situ mesocosms: Denitrification in the Elk Valley aquifer. Ground Water Monit. Rem. 25:79-89.

Lapham, W.W., F.D. Wilde, and M.T. Koterba. 1997. Guidelines and standard procedures for studies of ground water quality: Selection and installation of wells, and supporting documentation. Water Resour. Invest. Rep. USGS. 96-4233. USGS, Washington, DC.

Mariotti, A., A. Landreau, and B. Simon. 1988. N isotope biogeochemistry and natural denitrification process in groundwater-Application to the chalk aquifer of northern France. Geochim. Cosmochim. Acta 52:1869-1878.

McMahon, P.B., and J.K. Böhlke. 1996. Denitrification and mixing in a stream-aquifer system: Effects on nitrate loading to surface water. J. Hydrol. 186:105-128. 
McMahon, P.B., J.K. Böhlke, and S.C. Christenson. 2004. Geochemistry, radiocarbon ages, and paleorecharge conditions along a transect in the central High Plains aquifer, southwestern Kansas, USA. Appl. Geochem. 19:1655-1686.

McMahon, P.B., and F.H. Chapelle. 2007. Redox processes and the water quality of selected principal aquifer systems of the United States. Ground Water (in press).

Modica, E., H.T. Burton, and L.N. Plummer. 1998. Evaluating the source and residence times of groundwater seepage to streams: New Jersey Coastal Plain. Water Resour. Res. 34:2797-2810.

Mueller, D.K., and D.R. Helsel. 1996. Nutrients in the Nation's waters-Too much of a good thing? Circ. USGS. 1136. USGS, Washington, DC.

Nolan, B.T., and J.D. Stoner. 2000. Nutrients in ground waters of the coterminous United States, 1992-1995. Environ. Sci. Technol. 34:1156-1165.

Qi, H., T.B. Coplen, H. Geilman, W.A. Brand, and J.K. Böhlke. 2003. Two new organic reference materials for $\mathrm{d} 13 \mathrm{C}$ and $\mathrm{d} 15 \mathrm{~N}$ measurements and a new value for the d13C of NBS 22 oil. Rapid Commun. Mass Spectrom. 17:2483-2487.

Paradis, D., R. Martel, G. Karanta, R. Lefebvre, Y. Michaud, R. Therrien, and M. Nastev. 2007. Comparative study of methods for WHPA delineation. Ground Water 45:158-167.

Paschke, S.S., L.J. Kauffman, S.M. Eberts, and S.R. Hinkle. 2007. Overview of regional studies of the transport of anthropogenic and natural contaminants to public supply wells. In S.S. Paschke (ed.) Hydrogeologic settings and ground water flow simulations for regional studies of the transport of anthropogenic and natural contaminants to public-supply wells-Studies begun in 2001. Prof. Pap. USGS. 1737-A (in press).

Pollock, D.W. 1994. User's Guide for MODPATH/MODPATH-PLOT, Version 3: A particle tracking post-processing package for MODFLOW, the U.S. Geological Survey finite-difference ground water flow model. Open-File Rep. USGS. 94-464. USGS, Washington, DC.

Postma, D., C. Boesen, H. Kristiansen, and F. Larsen. 1991. Nitrate reduction in an unconfined aquifer: Water chemistry, reduction processes, and geochemical modeling. Water Resour. Res. 27:2027-2045.

Puckett, L.J. 1995. Identifying the major sources of nutrient water pollution. Environ. Sci. Technol. 29:408A-414A.

Puckett, L.J., and T.K. Cowdery. 2002. Transport and fate of nitrogen in a glacial outwash aquifer in relation to ground water age, land use practices, and redox processes. J. Environ. Qual. 31:782-796.

Puckett, L.J., T.K. Cowdery, P.B. McMahon, L.H. Tornes, and J.D. Stoner. 2002. Using chemical, hydrologic, and age dating analysis to delineate redox processes and flow paths in the riparian zone of a glacial outwash aquiferstream system. Water Resour. Res. 38:1134 doi:10.1029/2001WR000396

Puckett, L.J., C. Zamora, H.E. Essaid, J.T. Wilson, H.M. Johnson, M.J. Brayton, and J.R. Vogel. 2008. Transport and fate of nitrate at the ground water-surface water interface. J. Environ. Qual. 37:1034-1050.

Rayne, T.W., K.R. Bradbury, and M.A. Muldoon. 2001. Delineation of capture zones for municipal wells in fractured dolomite, Sturgeon Bay, Wisconsin, USA. Hydrogeol. J. 9:432-450.

Robertson, W.D., B.M. Russell, and J.A. Cherry. 1996. Attenuation of nitrate in aquitard sediments of southern Ontario. J. Hydrol. 180:267-281.

Ruddy, B.C., D.L. Lorenz, and D.K. Mueller. 2006. County-level estimates of nutrient inputs to the land surfaces of the coterminous United States, 1982 2001. Sci. Investigations Rep. USGS. 2006-5012. USGS, Washington, DC.

Rupert, M.G. 2007. Decadal-scale changes of nitrate in ground water of the United States, 1988-2004. J. Environ. Qual. (in press).

Schwarz, G.E., A.B. Hoos, R.B. Alexander, and R.A. Smith. 2006. The SPARROW surface water-quality model: Theory, application, and user documentation. USGS Techniques and Methods Report. Book 6, Chapter B3. USGS, Washington, DC.
Seitzinger, S.P., J. Harrison, J.K. Böhlke, A.F. Bouwman, R.R. Lowrance, B.J. Peterson, C.R. Tobias, and G. van Drecht. 2006. Denitrification across landscapes and waterscapes: A synthesis. Ecol. Appl. 16:2064-2090.

Siemens, J., M. Haas, and M. Kaupenjohann. 2003. Dissolved organic matter induced denitrification in subsoils and aquifers? Geoderma 113:253-271.

Sigman, D.M., K.L. Casciotti, M.C. Andreani, C. Barford, M. Galanter, and J.K. Böhlke. 2001. A bacterial method for the nitrogen isotopic analysis of nitrate in seawater and freshwater. Anal. Chem. 73:4145-4153.

Singleton, M.J., B.K. Esser, J.E. Moran, G.B. Hudson, W.W. McNab, and T. Harter. 2007. Saturated zone denitrification: Potential for natural attenuation of nitrate contamination in shallow groundwater under dairy operations. Environ. Sci. Technol. 41:759-765.

Smith, R.L., B.L. Howes, and J.H. Duff. 1991. Denitrification in nitratecontaminated ground water: Occurrence in steep vertical geochemical gradients. Geochim. Cosmochim. Acta 55:1815-1825.

Starr, R.C., and R.W. Gillham. 1989. Controls on denitrification in shallow unconfined aquifers. p. 51-56. In H.E. Kobus and W. Kinzelbach (ed.) Contaminant transport in ground water. A.A. Balkema, Rotterdam.

Starr, R.C., and R.W. Gillham. 1993. Denitrification and organic carbon availability in two aquifers. Ground Water 31:934-947.

Systat Software Inc. 2006. SigmaStat Users' Guide. Systat Software, Inc., Point Richmond, CA.

Tesoriero, A.J., H. Liebscher, and S.E. Cox. 2000. The mechanism and rate of denitrification in an agricultural watershed: Electron and mass balance along ground water flow paths. Water Resour. Res. 36:1545-1559.

Tesoriero, A.J., T.B. Spruill, H.E. Mew, Jr., K.M. Farrell, and S.L. Harden. 2005. Nitrogen transport and transformations in a coastal plain watershed: Influence of geomorphology on flow paths and residence times. Water Resour. Res. 41:W02008 doi:10.1029/2003WR002953.

Thatcher, L.L., V.J. Janzer, and K.W. Edwards. 1976. Methods for determination of radioactive substances in water and fluvial sediments. Techn. Water Resour. Invest. USGS chap. A5, 67-81. USGS, Washington, DC.

Trudell, M.R., R.W. Gillham, and J.A. Cherry. 1986. An in situ study of the occurrence and rate of denitrification in a shallow unconfined sand aquifer. J. Hydrol. 83:251-268.

van Beek, C.G.E.M., and J. van Puffelen. 1987. Changes in the chemical composition of drinking water after well infiltration in an unconsolidated sandy aquifer. Water Resour. Res. 23:69-76.

Vidon, P.G.F., and A.R. Hill. 2004. Landscape controls on the hydrology of stream riparian zones. J. Hydrol. 292:210-228.

Vogel, J.C., A.S. Talma, and T.H.E. Heaton. 1981. Gaseous nitrogen as evidence for denitrification in ground water. J. Hydrol. 50:191-200.

Weishaar, J.L., G.R. Aiken, B.A. Bergamaschi, M.S. Fram, R. Fujii, and K. Mopper. 2003. Evaluation of specific ultraviolet absorbance as an indicator of the chemical composition and reactivity of dissolved organic carbon. Environ. Sci. Technol. 37:4702-4708.

Weiss, R.F. 1970. The solubility of nitrogen, oxygen, and argon in water and seawater. Deep Sea Res. 17:721-735.

Weissmann, G.S., Y. Zhang, E.M. LaBolle, and G.E. Fogg. 2002. Dispersion of groundwater age in an alluvial aquifer system. Water Resour. Res. 38:1198 doi:10.1029/2001WR000907.

Well, R., H. Flessa, F. Jaradat, S. Toyoda, and N. Yoshida. 2005. Measurement of isotopomer signatures of $\mathrm{N}_{2} \mathrm{O}$ in groundwater. J. Geophys. Res. 110:G02006 doi:10.1029/2005JG000044.

World Health Organization. 2004. Guidelines for drinking water quality, 3rd ed. Volume 1-Recommendations. Geneva.

Zuber, A. 1986. Mathematical models for the interpretation of environmental radioisotopes in groundwater systems. p. 1-59. In P. Fritz and J.-C. Fontes (ed.) Handbook of environmental isotope geochemistry, Vol. 2. Elsevier, Amsterdam. 